UNIVERSIDADE ESTADUAL PAULISTA "JÚLIO DE MESQUITA FILHO" FACULDADE DE CIÊNCIAS AGRONÔMICAS

CAMPUS DE BOTUCATU

\title{
DESENVOLVIMENTO DE PLANTAS DE SORGO SUBMETIDAS A DIFERENTES NÍVEIS DE LENÇOL FREÁTICO
}

\author{
ADRIANA AKI TANAKA
}

Dissertação apresentada à Faculdade de Ciências Agronômicas da UNESP - Campus de Botucatu, para a obtenção do título de Mestre em Agronomia (Irrigação e Drenagem).

BOTUCATU - SP

Fevereiro 2010 


\section{UNIVERSIDADE ESTADUAL PAULISTA “JÚLIO DE MESQUITA FILHO” FACULDADE DE CIÊNCIAS AGRONÔMICAS CAMPUS DE BOTUCATU}

\section{DESENVOLVIMENTO DE PLANTAS DE SORGO SUBMETIDAS A DIFERENTES NÍVEIS DE LENÇOL FREÁTICO}

\section{ADRIANA AKI TANAKA}

Orientador: Prof. Dr. Antonio Evaldo Klar

Dissertação apresentada à Faculdade de Ciências Agronômicas da UNESP - Campus de Botucatu, para a obtenção do título de Mestre em Agronomia (Irrigação e Drenagem).

BOTUCATU - SP

Fevereiro 2010 
FICHA CATALOGRÁFICA ELABORADA PELA SEÇÃO TÉCNICA DE AQUISIÇÃO E TRATAMENTO DA INFORMAÇÃO - SERVIÇO TÉCNICO DE BIBLIOTECA E DOCUMENTAÇÃ̃O - UNESP - FCA - LAGEADO - BOTUCATU (SP)

naka, Adriana Aki, 1983-

Desenvolvimento de plantas de sorgo submetidas a diferentes níveis de lençol freático / Adriana Aki Tanaka. Botucatu : [s.n.], 2010.

vi, 54 f. : il., tabs., gráfs., fots. color

Dissertação (Mestrado) - Universidade Estadual Paulis-

ta, Faculdade de Ciências Agronômicas, Botucatu, 2010

Orientador: Antonio Evaldo Klar

Inclui bibliografia.

1. Sorgo. 2. Lençol freático. 3. Características agronômicas. 4. Evapotranspiração. 5. Kc. I. Klar, Antonio Evaldo. II. Universidade Estadual Paulista "Júlio de Mesquita Filho" (Campus de Botucatu). Faculdade de Ciências Agronômicas. III. Título. 


\title{
UNIVERSIDADE ESTADUAL PAULISTA "JÚLIO DE MESQUITA FILHO" FACULDADE DE CIÊNCIAS AGRONÔMICAS \\ CAMPUS DE BOTUCATU
}

\author{
CERTIFICADO DE APROVAÇÃO
}

\section{TítUlO: "DESENVOLVIMENTO DE PLANTAS DE SORGO SUBMETIDAS A DIFERENTES NÍVEIS DE LENÇOL FREÁTICO"}

\author{
ALUNA: ADRIANA AKI TANAKA \\ ORIENTADOR: PROF. DR. ANTONIO EVALDO KLAR
}

Aprovado pela Comissão Examinadora

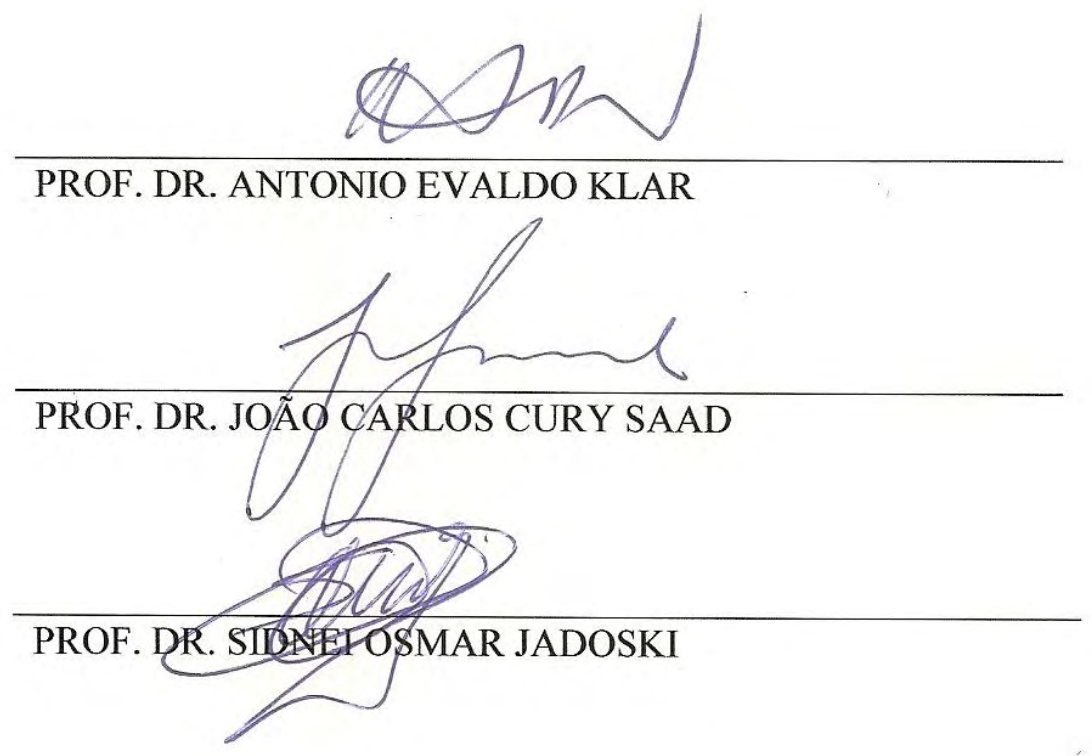

Data da Realização: 08 de Fevereiro de 2010. 
$\grave{A}$ todas as pessoas que me apoiaram e incentivaram em todos os momentos da minha vida.

A Neusa, minha mãe; Marcelo e Edson, meus irmãos e Miyoko, minha avó, pelo apoio, confiança e incentivo a superar cada etapa e desafio. 


\section{AGRADECIMENTOS}

À Deus por sempre me guiar e conceder vida e saúde para realizar meus objetivos.

À meus tios, tias, primos e primas que sempre me apoiaram e acreditaram em minha formação.

Ao professor Antonio Evaldo Klar pelo conhecimento, orientação, incentivo, confiança e amizade a mim concedidos.

Aos professores do Departamento de Engenharia Rural por seus ensinamentos e ajuda na minha formação profissional.

Aos funcionários do Departamento Dejair, Rita e, especialmente ao Gilberto por estar sempre disposto a ajudar seja qual fosse o dia.

Aos meus amigos Cleber e Mayara pela ajuda durante toda a condução do experimento, contribuindo muito para a realização deste.

À meus amigos de sempre Kinha, Karen, Rebeca, Kátia, Lilian, Juscelino, Elcio, André, Marcos, Milton, e a todos meus amigos pela amizade sincera todos estes anos e que estão sempre torcendo por mim.

Às minhas amigas Tatiana, Dione, Graziela, Loraya, Bruna, Simone, Priscila, Luciemy e Amanda, sempre presentes em minha vida, mesmo estando distantes, torcem e acreditam sempre que eu possa alcançar meus objetivos.

À minha "irmã" Rosilaine e seus familiares pelos momentos de alegria, e apoio nos momentos difíceis da minha vida.

Aos meus amigos botucatuenses muito importantes na minha vida Juliana, Marcela, Thaise, Emi, Danila, Simoni, Edvar, Giovanna, Hélio, Anthony, Marlon e a todos que sempre me incentivam.

Aos meus amigos Adilson, Andréa e Manoel pela parceria, amizade sincera e auxílio sempre que foi necessário.

Muito Obrigada! 


\section{SUMÁRIO}

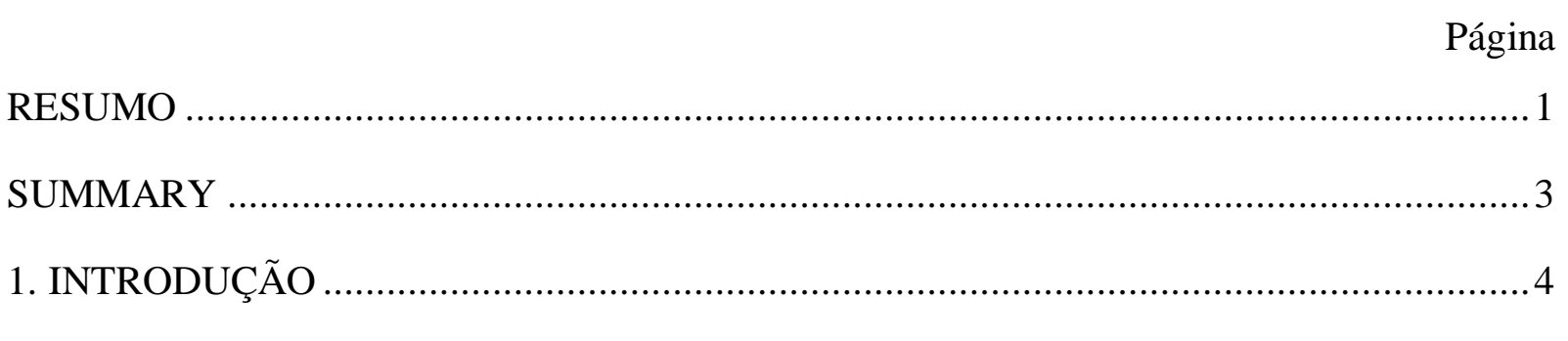

2. REVISÃO DE LITERATURA........................................................................ 7

2.1. A cultura de sorgo ..................................................................................... 7

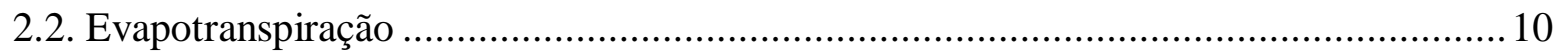

2.3 Eficiência do uso da água pelas plantas ........................................................... 15

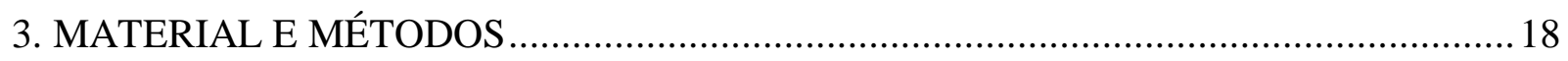

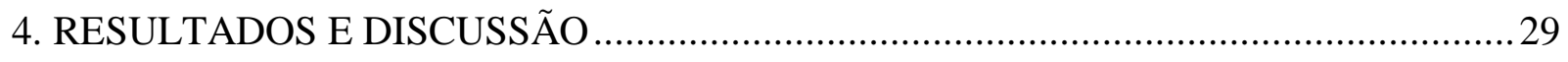

4.1. Características agronômicas da cultura do sorgo em diferentes níveis freáticos..........29

4.1.1. Potencial matricial e umidade do solo .......................................................... 30

4.1.2. Florescimento das plantas de sorgo submetidas a diferentes níveis de lençol freático em casa de vegetação..................................................................... 32

4.1.3. Massa da matéria fresca e seca da parte aérea das plantas de sorgo. .................... 32

4.1.4. Altura e diâmetro das plantas de sorgo ............................................... 34

4.1.5. Massa da matéria seca das raízes: total e particionada em camadas $(7 \mathrm{~cm}) \ldots \ldots \ldots . . . .36$

4.1.6. Massa da matéria fresca, massa da matéria seca e comprimento das panículas. ....40 4.2. Evapotranspiração da cultura do sorgo em diferentes níveis freáticos e eficiência do uso

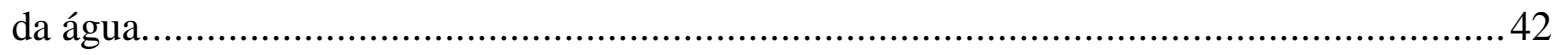

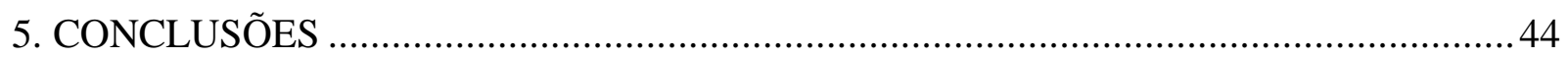

6. REFERÊNCIAS BIBLIOGRÁFICAS ................................................................ 46 


\section{LISTA DE TABELAS}

Página

Tabela 1. Análise química do solo da área experimental do Departamento de Engenharia Rural na profundidade de $0-0,20 \mathrm{~m}$.

Tabela 2. Análise física do solo da área experimental do Departamento de Engenharia Rural na profundidade de $0-0,20 \mathrm{~m}$.

Tabela 3. Relações entre os potenciais e os teores de água do solo.

Tabela 4. Porcentagem de emergência das plântulas de sorgo (Sorghum bicolor L. Moench) submetidas a diferentes níveis de lençol freático, em casa de vegetação.

Tabela 5. Potencial matricial ( - MPa), por camadas, a partir do nível de lençol freático à superfície do solo.

Tabela 6. Umidade do solo $\left(\mathrm{cm}^{3} \mathrm{~cm}^{-3}\right)$, por camadas, a partir do nível de lençol freático à superfície do solo

Tabela 7. Período de florescimento das plantas de sorgo (Sorghum bicolor L. Moench) submetidas a diferentes níveis de lençol freático, em casa de vegetação.

Tabela 8. Massa da matéria seca das raízes de sorgo (Sorghum bicolor L. Moench) particionadas nas diferentes profundidades do solo $(7 \mathrm{~cm})$ nos diferentes níveis de lençol freático.

Tabela 9. Porcentagem de ar e água nas diferentes profundidades $(7 \mathrm{~cm})$ em cada nível de lençol freático.

Tabela 10. Porcentagem da quantidade de raízes de sorgo (Sorghum bicolor L. Moench) nas diferentes profundidades $(7 \mathrm{~cm})$ nos diferentes níveis de lençol freático.

Tabela 11. Evapotranspiração de referência (ETo), evapotranspiração da cultura (ETc) decendiais e coeficiente da cultura $(\mathrm{Kc})$ médio decendial da cultura do sorgo (Sorghum bicolor L. Moench) submetidas a diferentes níveis de lençol freático. 


\section{LISTA DE FIGURAS}

Página

Figura 1. Fases fenológicas da planta de sorgo (Sorghum bicolor L. Moench)............... 9

Figura 2. Conjunto de vasos e bandejas para a mensuração da evapotranspiração da cultura

Figura 3. Vista do experimento dentro e fora da casa de vegetação.

Figura 4. Reservatório, bandeja e tubos.

Figura 5. Temperatura máxima, temperatura do bulbo seco, temperatura do bulbo úmido e temperatura média dentro da casa de vegetação no período de 24/12/2008 a 23/03/2009.

Figura 6. Evaporação do tanque dentro da casa de vegetação no período de 24/12/2008 a 23/03/2009.

Figura 7. Umidade Relativa dentro da casa de vegetação no período de 24/12/2008 a 23/03/2009.

Figura 8. Massa fresca e seca da parte aérea, em g, das plantas de sorgo (Sorghum bicolor L. Moench) submetidas aos diferentes níveis de lençol freático, pelo Teste Tukey a $5 \%$ de probabilidade.

Figura 9. Altura das plantas de sorgo (Sorghum bicolor L. Moench), em cm, submetidas a diferentes níveis de lençol freático, pelo teste Tukey a $5 \%$ de probabilidade.

Figura 10. Diâmetro do colmo, em mm, das plantas de sorgo (Sorghum bicolor L. Moench) submetidas a diferentes níveis de lençol freático, pelo teste Tukey a 5\% de probabilidade.

Figura 11. Área foliar das plantas de sorgo (Sorghum bicolor L. Moench) submetidas a diferentes níveis de lençol freático.

Figura 12. Número de folhas das plantas de sorgo (Sorghum bicolor L. Moench) submetidas a diferentes níveis de lençol freático.

Figura 13. Massa da matéria seca total das raízes, em g, das plantas de sorgo (Sorghum bicolor L. Moench) submetidas a diferentes níveis de lençol freático, pelo teste Tukey a $5 \%$ de probabilidade. 
Figura 14. Massa fresca e seca das panículas, em g, de sorgo (Sorghum bicolor L. 40Moench) submetidas a diferentes níveis de lençol freático, pelo teste Tukey a 5\% de significância.

Figura 15. Comprimento das panículas, em $\mathrm{cm}$, das plantas de sorgo (Sorghum bicolor L. Moench) submetidas a diferentes níveis de lençol freático, pelo teste Tukey a 5\% de probabilidade.

Figura 16. Eficiência do uso da água pelas plantas de sorgo (Sorghum bicolor L. Moench) submetidas a diferentes níveis de lençol freático.... 
DESENVOLVIMENTO DE PLANTAS DE SORGO SUBMETIDAS A DIFERENTES NÍVEIS DE LENÇOL FREÁTICO. Botucatu, 2010. 54 p. Dissertação (Mestrado em Agronomia / Irrigação e Drenagem) - Faculdade de Ciências Agronômicas, Universidade Estadual Paulista.

Autora: ADRIANA AKI TANAKA

Orientador: ANTONIO EVALDO KLAR

\section{RESUMO}

A planta de sorgo, apesar de possuir menor valor nutritivo que o milho, tolera mais o déficit de água e o excesso de umidade no solo, assim como situações ambientais muito secas e/ou muito quentes nas quais a produtividade de outros cereais é antieconômica. Possui muitas aptidões, dentre as quais a de forrageiro para silagem e/ou sacarino; forrageiro para cobertura morta e granífero. O objetivo do trabalho foi avaliar o desenvolvimento das plantas de sorgo (Sorghum bicolor L. Moench) submetidas a diferentes níveis de lençol freático. O presente projeto foi realizado em estufa de vidro, sobre bandejas com reservatórios de água que permitiam a subirrigação e vasos constituídos de tubos de PVC (15 cm de diâmetro) com diferentes alturas simulando diferentes níveis de lençol freático com seis profundidades $(0,17 \mathrm{~m} ; 0,31 \mathrm{~m} ; 0,45 \mathrm{~m}$; $0,59 \mathrm{~m} ; 0,73 \mathrm{~m}$ e $0,87 \mathrm{~m}$ de profundidade; tratamentos $\mathrm{T} 1 ; \mathrm{T} 2 ; \mathrm{T} 3 ; \mathrm{T} 4 ; \mathrm{T} 5$ e $\mathrm{T} 6$ respectivamente) em delineamento inteiramente casualizado. Os parâmetros analisados foram: massa da matéria fresca, seca, altura e diâmetro das plantas; massa da matéria fresca, seca comprimento das panículas; massa da matéria seca das raízes total e particionada em diferentes profundidades $(7 \mathrm{~cm})$; área foliar; número de folhas; evapotranspiração da cultura (ETc); coeficiente da cultura (Kc) e eficiência do uso da água. A análise estatística dos dados foi feita pela comparação de médias, teste Tukey com 5\% de probabilidade. O tratamento T6 não foi considerado nas análises por falta de plantas suficientes. Os resultados nas condições deste experimento permitiram as seguintes conclusões: foram observadas diferenças no desenvolvimento das plantas submetidas a diferentes níveis de lençol freático; as profundidades de níveis de lençol freático abaixo de $73 \mathrm{~cm}$, não seriam recomendadas, pois não se observou emergência de plantas e, profundidades de níveis freáticos menores que 17 $\mathrm{cm}$ não seriam recomendadas, pois se verificou o menor desenvolvimento do sistema radicular prejudicando o desenvolvimento das plantas; as profundidades com lençol freático entre 45 e 
$59 \mathrm{~cm}$ foram os melhores, apresentando os maiores valores para ambas as massas, fresca e seca; para as panículas, os maiores valores para as massas de matéria fresca e seca, bem como o comprimento apresentaram tendência aos maiores valores para os níveis de lençol de 59 e 73 cm; com relação ao diâmetro do colmo, não houve significância estatística entre os tratamentos 45, 59 e $73 \mathrm{~cm}$, porém estes foram significativamente diferentes das cultivadas em níveis freáticos mais próximos da superfície, observando-se assim que os níveis de lençol freático mais profundos induziram as plantas a produzirem colmos mais grossos; a evapotranspiração da cultura apresentou valores entre115 a 184,58 mm; os valores de Kc (ETc/Eto) tiveram médias 0,47 no estádio inicial (da germinação à emissão da panícula) e 1,46 no estádio seguinte (início do florescimento ao final deste).

Palavras chave: sorgo, lençol freático, características agronômicas, evapotranspiração, Kc. 
DEVELOPMENT OF SORGHUM PLANTS SUBMITTED TO DIFFERENT WATER TABLE TREATMENTS. Botucatu, 2010. 54 p. (Master in Agronomy / Irrigation and Drainage) - Faculty of Agronomic Sciences, State University of São Paulo.

Author: ADRIANA AKI TANAKA

Adviser: ANTONIO EVALDO KLAR

\section{SUMMARY}

This study aimed to evaluate the development of sorghum plants (Sorghum bicolor L. Moench) submitted to different water table treatments. The experiment was carried out in a glasshouse on trays with water reservoirs that allowed sub irrigation, and vases made of PVC tubes (15 cm diameter) with different heights simulating different levels of a water table with six depths $(17 \mathrm{~cm} ; 31 \mathrm{~cm} ; 45 \mathrm{~cm} ; 59 \mathrm{~cm} ; 73 \mathrm{~cm}$ and $87 \mathrm{~cm}$; treatments T1; T2; T3; T4; T5 and T6 respectively) in a entirely random design. The analyzed parameters were: fresh matter, dry matter, length and diameter of plants; fresh matter, dry matter and length of panicles; total dry matter of roots and parted into rings $(7 \mathrm{~cm})$; leaf area; crop evapotranspiration; Kc and water use efficiency. The data statistical analysis was done by comparing means using Tukey's test at 5\%. Treatment T6 was not considered in the analysis because of the lack of sufficient plants. Under the conditions of this experiment, it was possible to observe that were differences in plant growth under different levels of water table; the water table under $73 \mathrm{~cm}$ were not recommended, because there was not emergence of plants and water table depths of less than $17 \mathrm{~cm}$ would not be recommended, because there was the less-developed root system damaging plant growth; the water table depths between 45 and $59 \mathrm{~cm}$ were the best, with higher values for both matter, fresh and dry; to the panicle, the highest values for matter fresh and dry weight and length tended to higher values for the water table of 59 and $73 \mathrm{~cm}$; regarding the stem diameter, there was no statistical significance among the treatments at 45 , 59 and $73 \mathrm{~cm}$, however, they were significantly different from the plants cultivated at water table levels closer to the surface, observing that levels of water table deeper induced plants to produce thicker stems, the crop evapotranspiration values were entre115 to $184.58 \mathrm{~mm}$, the values of $\mathrm{Kc}$ (ETc / ETo) were 0.47 average at the initial stage (germination to panicle emergence) and 1.46 in the next stage (early flowering at the end of this).

Keywords: sorghum, groundwater, agronomic characteristics, evapotranspiration, Kc. 


\section{INTRODUÇÃO}

O sorgo (Sorghum bicolor L. Moench) é o quinto cereal mais importante no mundo, antecedido pelo trigo, arroz, milho e cevada. Entre as espécies alimentares é uma das mais versáteis e eficientes, tanto do ponto de vista fotossintético, como em velocidade de maturação (RIBAS, 2003). Sua reconhecida versatilidade se estende desde o uso de seus grãos como alimento humano e animal; como matéria prima para produção de álcool anidro, bebidas alcoólicas, colas e tintas; o uso de suas panículas para produção de vassouras; extração de açúcar de seus colmos; até às inúmeras aplicações de sua forragem na nutrição de ruminantes.

O seu cultivo é muito antigo, tendo-se notícias de sua exploração no Egito, China e Índia, onde era cultivado muito antes da Era Cristã. Contudo, o desenvolvimento da cultura em muitas regiões agrícolas ocorreu somente no final do século passado.

No Brasil, desde a década de 70, houve incentivo ao plantio do sorgo para estabelecer-se e firmar-se como uma alternativa para aumentar a disponibilidade de grãos no país, que se encontrava estacionada num patamar inferior a 500 mil toneladas anuais. A cultura do sorgo sofreu diversas pressões, principalmente por parte de pesquisadores que viam nessa cultura uma ameaça ao milho, não só como um produto similar, mas principalmente, por considerá-la como um perigo sob o ponto de vista fitopatológico, como potencial transmissor de doenças e hospedeiro de pragas para o milho. 
O sorgo pode ser cultivado no período das águas no Centro-Sul, tal como o milho, mas economicamente se apresenta menos rentável e, por esse motivo, tem sido explorado no período da seca (como segunda safra), normalmente quando, por problemas climáticos, a época recomendada de semeadura do milho safrinha termina e torna-se menos arriscado o plantio do sorgo. Esta cultura requer menos água para se desenvolver, quando comparado com outros cereais e, quando comparado com o milho, o sorgo produz mais sobre estresse hídrico (raiz explora melhor o perfil do solo), murcha menos e é capaz de se recuperar de murchas prolongadas (MAGALHÃES e DURÃES, 2003).

A produção brasileira de grãos depende quase que exclusivamente da precipitação pluviométrica. Em anos com a ocorrência de condições desfavoráveis, normalmente há déficit na produção de grãos e o sorgo, sendo uma cultura de vocação para cultivo em condições adversas de clima e solo, poderia reduzir o impacto desse fator no abastecimento de grãos. A planta de sorgo tolera mais o déficit de água e o excesso de umidade no solo, assim como situações ambientais de deficiência hídrica e/ou temperaturas mais elevadas, onde a produtividade de outros cereais é antieconômica.

A disponibilidade de água no solo às plantas é essencial para o desenvolvimento das culturas, sendo que a falta de chuvas pode ser suprida pelo uso da irrigação, entretanto, a instalação e operação de um sistema de irrigação não são garantias para aumentar a produtividade, pois seu manejo quando feito de forma inadequada, pode contribuir para a obtenção de baixas produtividades e, como conseqüência, aumentar significativamente os custos de produção. A prática da irrigação, desde que adequadamente alicerçada em bases científicas e tecnológicas, surge como um eficiente instrumento de aumento na oferta de produtos agrícolas e menores desperdícios.

Através dos anos, o homem tem usado a irrigação como um método para superar a falta de água às plantas. Este método é efetivo na redução do estresse, contudo, a distribuição das aplicações da água é crítica. Solos com excesso de umidade implicam em redução da taxa de oxigênio, uma vez que apresentam aeração deficiente, pois a água ocupa os poros do solo, fazendo com que os rendimentos das culturas se reduzam (KERBAUY, 2004). O problema se agrava quando não se dispõe de dados suficientes que permitam conhecer a diminuição da produção causada na cultura pelos diferentes níveis de lençol freático. 
Diante do exposto, o trabalho foi conduzido com o objetivo de avaliar o desenvolvimento das plantas de sorgo submetidas aos diferentes níveis de lençol freático. 


\section{REVISÃO DE LITERATURA}

\subsection{A cultura de sorgo}

A cultura do sorgo no Brasil, que era inexpressiva até 1970, cresceu significativamente desde então. Na safra de 2002/2003, a produção alcançou mais de dois milhões de toneladas de grãos, colocando o país entre os dez maiores produtores mundiais.

No mundo, o sorgo se caracteriza por ser o quinto cereal mais cultivado, com uma produção total superior a 60 milhões de toneladas, sendo equivalente a cerca de $10 \%$ da produção de milho, e, tem se destacado em razão da sua maior produtividade em condições adversas, principalmente de deficiência hídrica, baixa fertilidade do solo, amplitude na época de plantio e por mostrar maior tolerância a moléstias e pragas do que a cultura do milho (BOIN, 1985; DEMARCHI et al., 1995), além de possuir valor energético equivalente a 85 e $90 \%$ do milho (VALENTE, 1992).

O sorgo representa uma alternativa importante para auxiliar o abastecimento do mercado de grãos e, por suas características nutricionais, tem sido pesquisado como ingrediente energético alternativo ao milho. Geralmente apresenta preço inferior, com vantagens de cultivo em regiões de solos arenosos e clima seco por apresentar melhor rendimento de nutriente por unidade de área (SCHEUERMANN, 1998).

De acordo com a Companhia Nacional de Abastecimento (CONAB, 2009), nos últimos 19 anos, houve crescimento linear da produtividade do sorgo. A produção 
de sorgo granífero aumentou de 236 mil toneladas em 1990 para 1420 mil toneladas em 2007, sendo o auge da produção no ano de 2004 (MAPA, 2009). Existem cultivares de sorgo para a produção de massa verde para pastoreio (feno e silagem), para a produção de álcool ou açúcar e para a produção de vassouras (SAWAZAKI, 1998).

Segundo Ramalho et al. (1993) para minimizar os efeitos da interação cultivares $\mathrm{x}$ ambientes, é necessário identificar cultivares mais estáveis e adaptados às condições específicas de ambiente.

A antecipação da semeadura do sorgo tem demonstrado vantagens em alguns trabalhos (AVELAR \& MORAIS, 1986; MACHADO et al., 1987). No Brasil, porém, informações sobre a adaptabilidade e estabilidade do sorgo são escassas. As análises do comportamento de cultivares são de extrema importância para verificar a sua performance ao longo dos meses de cultivo (SILVA et al., 2005).

Embora apresente, em média, valor nutritivo levemente inferior à planta do milho, o sorgo é mais tolerante à seca (CUMMINS, 1981; LUSK et al., 1984) e esse diferencial é importante para os sistemas de produção situados em regiões sujeitas a veranicos e que não dispõem de irrigação artificial. A cultura do sorgo apresenta grande potencial de produção em regiões com precipitação irregular devido a sua capacidade de adaptação, tolerância a temperaturas elevadas e também por possuir características de xerofilia (REIS, 1992). O sorgo forrageiro, por exemplo, apresenta expectativa de crescimento no seu cultivo em áreas do semi-árido nordestino, devido a sua característica xerófila e por recuperar-se após estresse, assegurando a produção sob condições adversas (SCAPIM et al., 1998). 


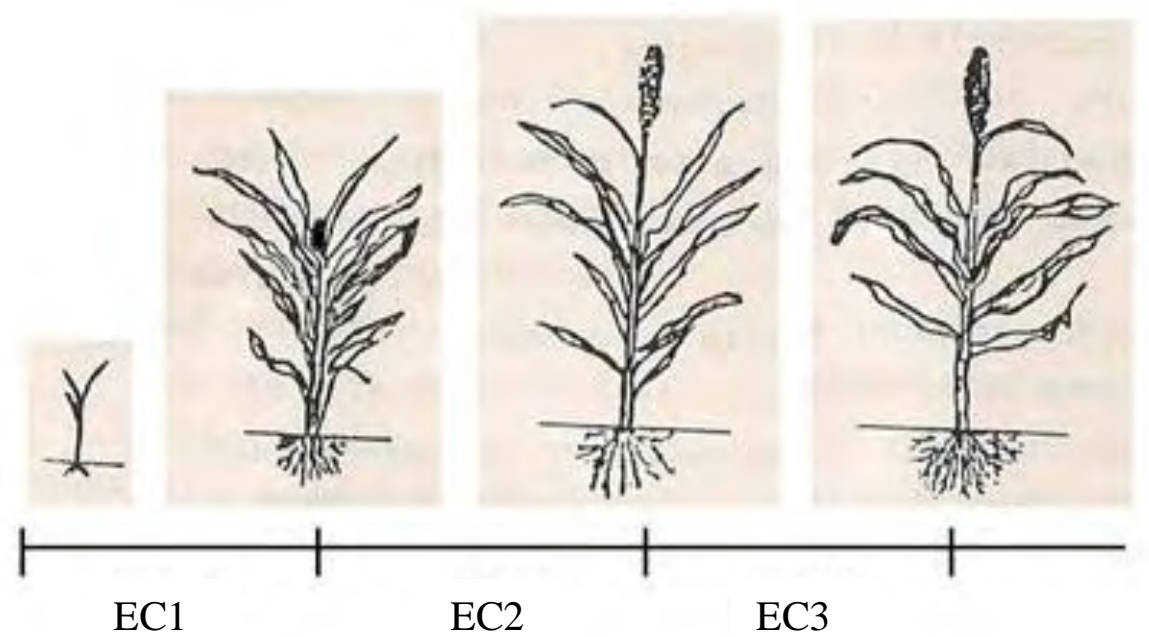

Figura 1. Fases fenológicas da planta de sorgo (Sorghum bicolor L. Moench)

A Figura 1 representa as fases fenológicas da cultura do sorgo. A primeira fase de crescimento da cultura, estádio de crescimento 1 (EC1), vai do plantio à iniciação da panícula. A fase seguinte, estádio de crescimento 2 (EC2), compreende a iniciação da panícula até o florescimento e, o estádio de crescimento 3 (EC3) corresponde o período de floração até a maturidade fisiológica (MAGALHÃES e DURÃES, 2003). A duração de cada estádio de crescimento depende da cultivar e das condições climáticas do local.

O sorgo caracteriza-se por responder relativamente bem a pequenas quantidades de água, aplicadas nas épocas críticas a falta desta. Para o sorgo, este período crítico é o reprodutivo, especialmente a fase de florescimento correspondente ao estádio EC3, que engloba a polinização, fertilização, desenvolvimento e maturação do grão (ABMS, 1989; MAGALHÃES e DURÃES, 2003).

Diversos experimentos têm sido conduzidos para caracterizar o comportamento do sorgo granífero sob condições de déficit hídrico. Entretanto, este comportamento tem demonstrado grande variação em função dos diferentes locais, práticas de manejo, tipos de solo e cultivares utilizadas (ROSENTHAL et al., 1987; GARRITY et al., 1982; MAGALHÃES et al., 1994). Rosenthal et al., (1987) descrevem os efeitos do déficit hídrico no desenvolvimento foliar e na transpiração em plantas de sorgo. Estes autores utilizaram a fração da água disponível (FAD) às plantas, para caracterizar a quantidade de 
água existente no perfil de solo, quando a transpiração e o desenvolvimento foliar decrescem de sua taxa potencial.

\subsection{Evapotranspiração}

Atualmente, a irrigação é considerada uma prática fundamental, para garantir a estabilidade das colheitas, elevar o índice de produtividade das culturas e permitir a incorporação de áreas com precipitações reduzidas ou mal distribuídas ao longo do ciclo. Moura et al., (1993) destacaram que o sucesso da irrigação envolve muito mais fatores do que a instalação e operação de um equipamento de irrigação. Para a maximização da produtividade, é necessário aplicar a quantidade requerida de água no momento adequado.

A investigação experimental sobre a evapotranspiração, visando determinar as necessidades hídricas das culturas, vem sendo exaustivamente estudada nas últimas décadas, em função da necessidade de se conduzir a irrigação de forma racional dentro da realidade de cada região (LUNARDI, 2000).

O limite superior de produção de uma cultura é determinado pelas condições ambientais e seu pelo potencial genético. Até que ponto pode-se alcançar esse limite dependerá sempre da precisão com que os aspectos de engenharia de suprimento de água estiverem em consonância com as necessidades biológicas na produção da cultura. Portanto, a utilização eficiente da água na produção das culturas só poderá ser alcançada quando o planejamento, o projeto e a operação de suprimento de água e do sistema de distribuição estiverem orientados com o propósito de atender, em quantidade e tempo requerido, incluindo os períodos de escassez de água, às necessidades hídricas da cultura para ótimo crescimento e altos rendimentos (DOORENBOS e KASSAM, 1994).

A necessidade hídrica de uma cultura e as condições de solo são fatores primordiais para o dimensionamento de um sistema de irrigação, de modo que o fluxo de água atenda qualquer demanda atmosférica (FOLEGATTI, 1988; REICHARDT, 1996; PEREIRA et al., 1997).

Conforme relata Daker (1984), cada planta tem habilidade própria em extrair água do solo, e este tem características próprias para liberar água para as plantas a diferentes tensões matriciais. Normalmente se estabelece um limite inferior de disponibilidade 
de água para cada cultura e solo, que é definido em função do rendimento e do custo/benefício desejado para a cultura.

Segundo Klar (1984), a definição dada pela Sociedade Internacional de Ciência do Solo (I. S. S. S.) para o potencial de água no solo é: "a quantidade de trabalho que deve desenvolver-se para uma unidade de água pura ser transportada, reversível e isotermicamente, de um ponto de referência à elevação específica, sob pressão atmosférica, à mesma temperatura, ao ponto em consideração".

O sistema radicular da cultura é responsável pela relação entre o solo e planta. O conhecimento da sua distribuição no solo permite a adequação de práticas de cultivo, tais como manejo e fertilização do solo, além de se constituir em requisito para elaboração de projetos e execução do manejo de irrigação (COELHO et al., 2001).

O potencial de água na planta depende da habilidade das raízes em absorver a água do solo com que estão em contato, bem como das propriedades do solo no fornecimento e na condução desta água até as raízes numa proporção que satisfaça as exigências da transpiração. Uma das maneiras mais utilizadas de quantificação do consumo de água é através da medida da evapotranspiração (FRONZA, 2002).

As necessidades hídricas de uma cultura são normalmente expressas mediante a taxa de evapotranspiração (ET), em mmdia ${ }^{-1}$. O conhecimento dos valores de evapotranspiração das plantas cultivadas é dado fundamental para apreciar as exigências em água de cada cultura. O cálculo preciso da evapotranspiração e conseqüente exigência de irrigação não é simples e nem fácil, devido à complexidade do problema que inclui distintas variáveis, conseqüentes das conhecidas interrelações entre água, solo, atmosfera e planta (RODRIGUEZ, 1968).

Klar (1984) define a evapotranspiração como o somatório de transpiração e evaporação, referindo-se à água que penetra pelas raízes das plantas, utilizada na construção dos tecidos ou emitida pelas folhas, reintegrando-se na atmosfera, e a água evaporada pelo terreno nu, adjacente às plantas, ou por uma superfície de água ou pela superfície das folhas, quando molhadas por chuva ou irrigação, que não foi utilizada pelas plantas nos processos metabólicos. Em outras palavras, Reichardt (1990) considera a evapotranspiração como a transferência de água na forma de vapor, do sistema solo-planta para a atmosfera. 
A evapotranspiração, como componente do ciclo hidrológico, constitui-se em informação importante para o dimensionamento e manejo de sistemas de irrigação. Conhecendo-se a evapotranspiração, regime pluviométrico e perdas operacionais, torna-se possível dimensionar canais, tubulações, armazenamento e capacidade de bombeamento de um sistema de irrigação. Com relação ao manejo, o uso racional evita que a água seja ministrada em quantidades inferiores ou superiores àquelas requeridas pelas culturas (SEDIYAMA, 1987).

A evapotranspiração é controlada pela disponibilidade de energia, pela demanda atmosférica, e pelo suprimento de água do solo às plantas. A disponibilidade de energia depende do local, da época do ano e das condições atmosféricas. O local é caracterizado pelas coordenadas geográficas (latitude e altitude) e pela topografia. Num terreno plano, o total diário de radiação solar é modulado pela época do ano, que determina o ângulo de incidência dos raios solares, enquanto que, numa topografia acidentada, dependendo da estação do ano, terrenos com faces distintas terão disponibilidades diferentes de energia. A altitude afeta diretamente a temperatura do solo, do ar e a pressão atmosférica, que são fatores que influenciam a evapotranspiração. Para um determinado local, a disponibilidade de radiação é controlada pelo poder refletor da superfície (expresso pelo albedo), que possibilita um balanço de energia entre a entrada por meio de ondas curtas e saída por ondas longas (PEREIRA et al., 1997).

Para Doorenbos e Pruitt (1997), o clima é um dos fatores mais importantes na determinação do volume de água evapotranspirada pelas culturas. Excluindo-se os fatores climáticos, a evapotranspiração também é influenciada pela própria cultura (proporcional às suas características de crescimento), por práticas de manejo adotadas (espaçamento, cobertura morta, densidade de plantas) e por características do solo.

Essa demanda pode ser expressa como a evapotranspiração de referência (ETo) que, representa a taxa evapotranspiração de uma área extensa coberta por uma grama verde, de 8 a $15 \mathrm{~cm}$ de altura, em crescimento ativo, sombreando completamente o terreno e sem deficiência hídrica (DOORENBOS e KASSAM, 1994).

A ETo é tomada como um elemento meteorológico de referência para estudos comparativos de perda de água pela vegetação em diferentes situações e locais (REICHARDT, 1990). Já Smith et al., (1991) e Allen et al., (1998) definem evapotranspiração 
de referência como sendo aquela de uma cultura hipotética, com altura fixa de 0,12 $\mathrm{m}$, albedo

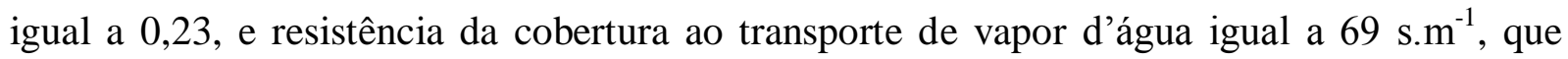
representaria a evapotranspiração de um gramado verde, de altura uniforme, em crescimento ativo cobrindo totalmente a superfície do solo, índice de área foliar próximo a $3 \mathrm{~m}^{2}$ folha. $\mathrm{m}^{-2}$ solo, e sem falta de água.

A evapotranspiração pode ser quantificada através de medidas diretas ou estimada indiretamente, com a utilização de modelos que baseiam-se em fatores que atuam no processo (VALADÃO, 1995), utilizando desde dados meteorológicos simples como o de Thornthwaite, baseado apenas na temperatura, até os mais complexos como o de Penman (PERES, 1994). De acordo com Sediyama (1987) e Burman \& Pochop (1994), existem mais de 50 métodos para a estimativa da evapotranspiração. A diversidade de resultados alcançados nos diferentes métodos, quase sempre, e causa de preocupações dos pesquisadores, que buscam definir melhor qual método estima a evapotranspiração corretamente (SEDIYAMA, 1987).

O balanço de água no sistema de controle é o princípio básico dos métodos de medida. Os lisímetros permitem determinar diretamente a evapotranspiração em condições controladas, onde o deflúvio superficial, a ascensão capilar e a drenagem profunda ou são minimizados e se tornam de fácil mensuração. Constituem-se em recipientes, cheios de solo e ao nível de superfície, representando as condições ambientais do campo onde estão localizados, quer seja utilizados para determinar a evapotranspiração de uma cultura ou de referência ou a evaporação do solo nu (ABOUKHALED et al., 1986).

Esses evapotranspirômetros podem ser empregados no monitoramento da percolação da água através do solo e na determinação dos constituintes solúveis removidos na drenagem. Valadão (1995), trabalhando com lisímetros de nível freático constante $(55 \mathrm{~cm})$, não verificou diferenças significativas entre as plantas de feijão desenvolvidas nos lisímetros e na bordadura, evidenciando o bom desempenho deste equipamento para a determinação do consumo de água pelas plantas.

Muçouçah (2005) cita trabalho realizado com lisímetros de drenagem, em Lisboa, que obteve diferenças que não excederam 10\% quando comparados com os métodos de Penman-Montheith FAO (PMF) e da Radiação para estimativa da evapotranspiração (ALLEN et al., 1998). 
Um grande número de métodos foi desenvolvido para a aplicação em partições de tempo maiores como meses e quinzenas e, quando aplicados em estimativas diárias apresentaram desempenhos inferiores quando comparados com outros métodos, como PMF. Ocorre freqüente incompatibilidade de aplicação de métodos em função da condição climática de origem do método. Por exemplo, um método desenvolvido em clima semi-árido não apresentará bons resultados quando aplicado em clima tropical.

A determinação da demanda hídrica de uma cultura permite o ajuste de diversas práticas de manejo entre elas a irrigação, bem como um melhor planejamento de lavouras no sentido de aumentar o potencial produtivo, promovendo reduções de riscos e de custos para produção e aumento da eficiência de utilização da água, principalmente em regiões ou épocas em que há limitações hídricas. O consumo de água pela cultura é tecnicamente denominado evapotranspiração da cultura (ETc) e pode ser medido ou estimado através de diferentes métodos.

A evapotranspiração da cultura pode ser determinada por métodos diretos ou indiretos. Os métodos diretos baseiam-se no balanço hídrico em volume de solo conhecido e os indiretos em parâmetros climáticos. Dentre os métodos de medida direta, os lisímetros se destacam por oferecer o maior nível de precisão para a determinação da evapotranspiração (PEREIRA et al., 1997).

A determinação do consumo de água e coeficientes de cultura $(\mathrm{Kc})$, através da utilização de lisímetros, vem sendo empregada no Brasil, utilizando-se entre outros, lisímetros de lençol freático constante, considerados precisos para estudos de culturas de pequeno porte (PAVANI, 1985).

$\mathrm{O}$ coeficiente da cultura $(\mathrm{Kc})$ relata o desenvolvimento fenológico e fisiológico de uma cultura particular em relação a evapotranspiração de referência e também representa o uso de água de uma cultura específica, que é de importância relevante para a estimativa do seu requerimento hídrico, necessário para o dimensionamento do sistema de irrigação quanto para operacionalização de perímetros irrigados (MOHAN \& ARUMUGAM, 1994). O Kc é função do tipo de cultura e, para uma mesma cultura, varia com o estádio de desenvolvimento das plantas e é obtido experimentalmente através da relação entre a evapotranspiração da cultura (ETc) e a evapotranspiração de referência (ETo) (DOORENBOS e PRUIT, 1977), sendo um indicador de grande significado físico e biológico, uma vez que 
depende da área foliar, arquitetura da planta, cobertura vegetal e transpiração da planta (DENMEAD e SHAW, 1962; JENSEN, 1969; WRIGHT, 1982; ALLEN et al., 1994; ALLEN et al., 1998, MEDEIROS et al., 2001).

\subsection{Eficiência do uso da água pelas plantas}

A deficiência hídrica é considerada a maior causa de redução na produtividade agrícola em clima tropical. Porém, como existe uma grande variabilidade na adaptação à seca entre espécies e dentro da espécie, deve-se avaliar o comportamento de diferentes materiais genéticos, em condições de seca, para a recomendação de cultivo (BLUM, 1997).

Por outro lado, o excesso de água tende a elevar o nível do lençol freático, trazendo-o para próximo da superfície do solo e prejudicando o desenvolvimento normal das culturas. $\mathrm{O}$ encharcamento de áreas pode ocorrer por precipitações pluviométricas abundantes, escorrimento de água das zonas elevadas ou transbordamento de rios, e ocorre especialmente quando o terreno possui baixa permeabilidade ou drenagem interna insuficiente (VIEIRA, 1988).

Um solo hipóxico, deficiente em oxigênio, pode se transformar em anóxico, ausência total de oxigênio, pela respiração dos órgãos submersos das plantas ou pelos microrganismos ali existentes. Nestes ambientes foi observada, para a maioria das plantas, uma redução do acúmulo de matéria seca e da produtividade e em períodos mais prolongados, a senescência das folhas e morte da planta (KERBAUY, 2004).

Alves et al. (1994), com o objetivo de verificar a importância da área do lisímetro na ascensão capilar, montaram uma bateria de colunas de solos em tubos de PVC com diâmetros diversos para analisar a possível influência de áreas reduzidas na ascensão capilar e concluíram que o diâmetro das colunas de solo não interfere na ascensão capilar, e, ainda, que este é um fenômeno específico do solo, independentemente do recipiente que o está confinando.

A economia de água pode aumentar a produção total por unidade de área disponível para o uso na agricultura, ou seja, aumentando a eficiência do uso da água. A eficiência do uso da água por uma cultura ou sistema produtivo é uma restrição básica nas 
decisões agronômicas, definindo o êxito na produção de biomassa pela água transpirada. A eficiência do uso da água pode ser baseada na evapotranspiração ou na transpiração da cultura; sendo que estas duas medidas de eficiência do uso da água podem ser baseadas na produção de matéria seca total ou do produto comercial (TANNER \& SINCLAIR, 1983).

Dinar (1993) considerou que a eficiência do uso da água relaciona a produção de biomassa ou produção comercial pela quantidade de água aplicada ou evapotranspirada; em agricultura irrigada, a elevação e a determinação dos níveis da eficiência do uso da água são bastante complexas e requerem conhecimento e considerações interdisciplinares.

A área foliar pode ser um importante fator para determinar a produtividade de uma comunidade vegetal (WINTER \& OHLROGGE, 1973). A avaliação cuidadosa da área foliar é sem dúvida um fator que auxilia na tomada de decisão para se eleger uma cultivar mais produtiva (MAGALHÃES, 1979).

As plantas verdes deparam com o dilema proposto pela necessidade de harmonizar dois vitais, mas contraditórios processos para o desenvolvimento das culturas. Por um lado, as plantas requerem uma rápida troca gasosa com a atmosfera para assimilação de $\mathrm{CO}_{2}$ e produção de biomassa; por outro lado, a manutenção de alta umidade das folhas requer mínima troca de gases com a atmosfera (STANHILL, 1986). E assim, estes dois processos estão relacionados com a transpiração das culturas, ou seja, a 'passagem da água pelas plantas', e, quanto mais eficiente este processo, mais produtiva a cultura. Portanto, o eficiente uso da água pelas culturas é extremamente importante, tanto em regiões áridas, como em regiões úmidas.

O eficiente uso da água em regiões áridas de agricultura irrigada é muito importante. A melhoria das técnicas de irrigação, redução da evaporação do solo, aumentando o reaproveitamento da água pelas culturas diminui a demanda de água. Estas considerações econômicas sobre o eficiente uso da água são igualmente importantes em regiões úmidas, desde que a irrigação suplementar produza aumentos na colheita. Estes ganhos na produtividade poderiam aumentar nas regiões úmidas com pequena quantidade de água, quando comparada com as regiões áridas. As precipitações estariam abastecendo, em grande parte, a água requerida, e as perdas por transpiração seriam menores em regiões úmidas, onde há grande disponibilidade de água (TANNER e SINCLAIR, 1983). 
A distribuição de água e a manutenção de níveis ótimos de umidade no solo durante o ciclo da cultura reduzem as perdas de água por percolação profunda e os períodos de estresse hídrico da cultura, o que aumenta a eficiência do uso da água (SOUZA et al., 2000). Dinar (1993) menciona que existem meios para se elevar os valores de eficiência do uso da água destacando-se entre esses, o manejo adequado da irrigação. 


\section{MATERIAL E MÉTODOS}

O trabalho foi conduzido na área experimental do Departamento de Engenharia Rural da Faculdade de Ciências Agronômicas da UNESP - Botucatu-SP, em uma casa de vegetação de vidro com $6 \mathrm{~m}$ de comprimento, $4 \mathrm{~m}$ de largura e $3 \mathrm{~m}$ de altura, provida de lanternim e janelas, pintada com faixas brancas de $10 \mathrm{~cm}$ de largura, de modo a possibilitar uma área pintada de 50\%, diminuindo a energia interna do ambiente.

O clima da região, de acordo com a classificação de Köeppen é definido como Cwa: clima temperado quente (mesotérmico) com chuvas no verão e seca no inverno, sendo a temperatura média do mês mais quente superior a $22^{\circ} \mathrm{C}$ (CEPAGRI, 2009). O local encontra-se a aproximadamente a $786 \mathrm{~m}$ de altitude e com as seguintes coordenadas geográficas: $22^{\circ} 51^{\prime}$ latitude Sul e $48^{\circ} 26^{\prime}$ longitude Oeste.

O período recomendado de cultivo pelo zoneamento agrícola do Estado de São Paulo para a cidade de Botucatu inicia-se no dia 10 de janeiro até dia 20 de fevereiro (MAPA, 2009).

A cultivar utilizada foi a Catissorgo, cultivar de dupla aptidão, ou seja, pode ser usada como forrageira e produção de grãos, e possui as seguintes características: ciclo de 115 dias para grãos, 90 dias para silagem; época de plantio de janeiro a março; época de florescimento de 70 a 75 dias após emergência; altura de 1,40 metros; massa fresca de 192 gramas por planta, massa seca de 58 gramas por planta, estande de 120 mil plantas por hectare (CATI, 2009). As sementes foram adquiridas na Casa da Agricultura da cidade de Botucatu. A 
semeadura ocorreu no dia 23 de dezembro de 2008 e a colheita no dia 23 de março de 2009. Foram semeadas cinco sementes por vaso, devidamente tratadas com captan (200 g i a. / 100 Kg sementes).

O conjunto para a mensuração da evapotranspiração da cultura (Figura 2) foi constituído de vasos confeccionados por tubos de PVC de diâmetro nominal de $150 \mathrm{~mm}$, com fundos fechados com capas de PVC, sendo perfurados para permitir a subirrigação e providos de manta geotêxtil para evitar a perda de solo. $\mathrm{O}$ vaso foi constituído por anéis de sete $\mathrm{cm}$ de altura, unidos por fita adesiva, formando tubos com altura de 0,$21 ; 0,35 ; 0,49 ; 0,63$; 0,77 e $0,91 \mathrm{~m}$. Os tubos foram semienterrados (cerca de $4 \mathrm{~cm}$ ), simulando seis profundidades de lençol freático $(0,17 ; 0,31 ; 0,45 ; 0,59 ; 0,73$ e $0,87 \mathrm{~m}$; tratamentos T1; T2; T3; T4; T5; T6 respectivamente), em bandejas metálicas pintadas de branco, com dimensões de 0,40 m de largura e 0,60 m de comprimento e altura de $0,14 \mathrm{~m}$, preenchidos com areia grossa lavada.

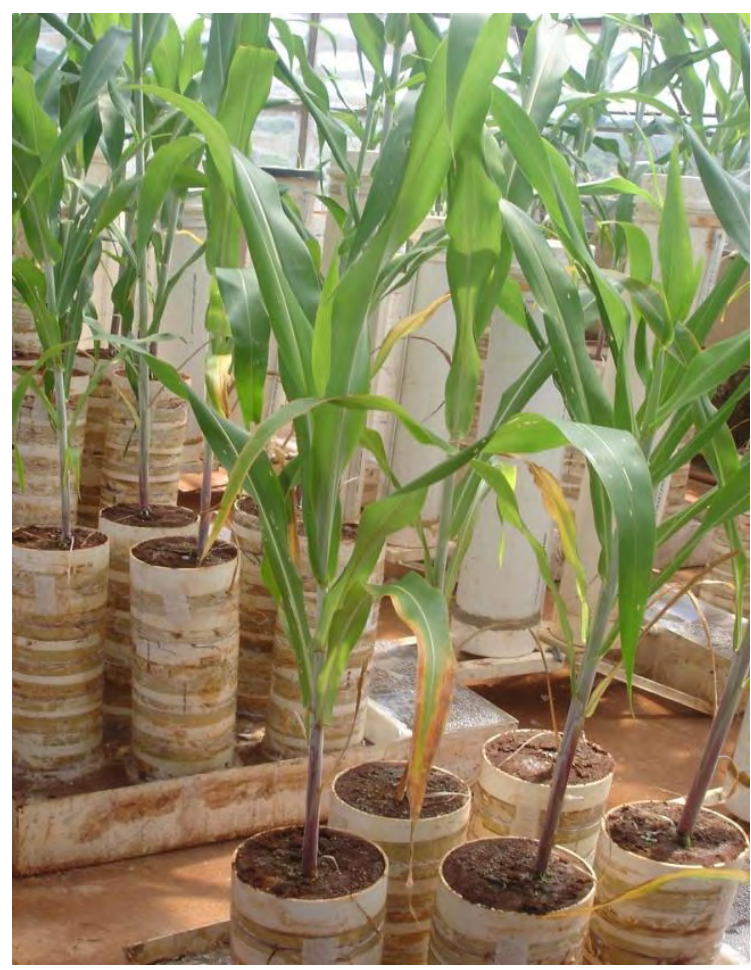

Figura 2. Conjunto de vasos e bandejas para a mensuração da evapotranspiração da cultura. 


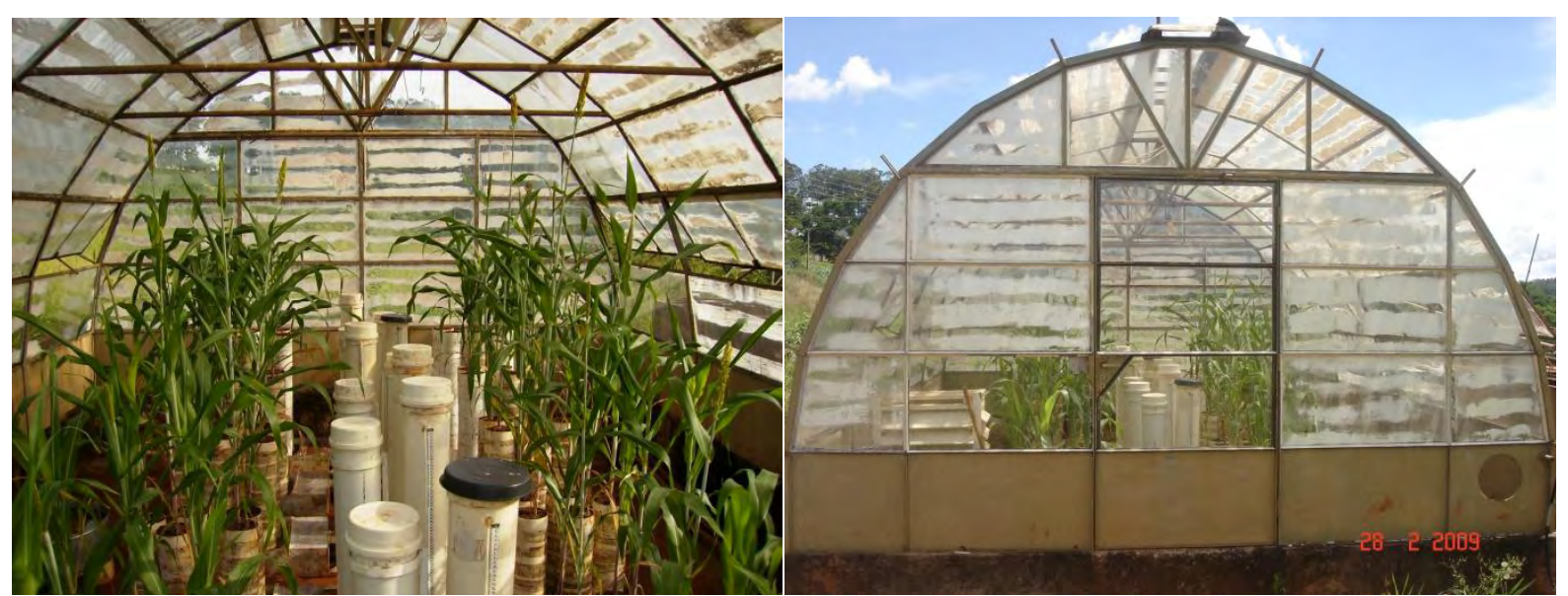

Figura 3. Vista do experimento dentro e fora da casa de vegetação.

O conjunto, bandeja, vasos preenchidos com solo, água nos reservatórios foi montado uma semana antes do plantio, com o objetivo de "estabilização" do processo de capilaridade conforme sugerido por Silveira e Klar (2006).

As bandejas eram dotadas de uma câmara intermediária provida de bóia para a manutenção do nível de água constante de acordo com o tratamento aplicado. Esta câmara era abastecida por um reservatório d'água graduado em milímetros, constituído de tubo de PVC de diâmetro nominal de $0,15 \mathrm{~m}$, com altura de $0,80 \mathrm{~m}$. O fornecimento de água da câmara intermediária à área útil da bandeja deu-se através de tubo de PVC de diâmetro nominal de 0,02 m. Com o objetivo de avaliar somente a evaporação dos vasos, os interstícios entre eles foram preenchidos com parafina e parte do reservatório foi vedado com isopor (Figura 4). 


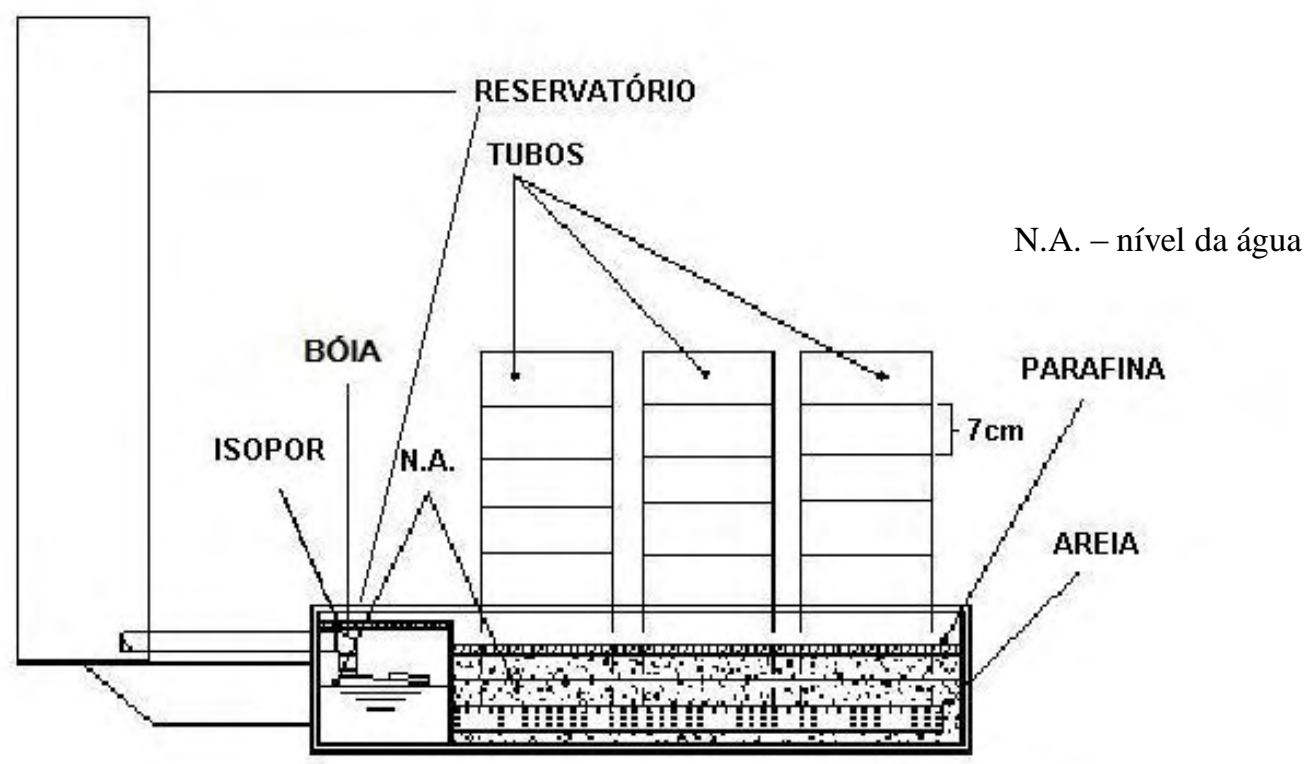

Fonte: Adaptado de Silveira e Klar, 2006.

Figura 4. Reservatório, bandeja e tubos.

O solo utilizado para o preenchimento dos vasos foi obtido de um terreno próximo à casa de vegetação, na área experimental do Departamento de Engenharia Rural, na camada de 0 a $0,2 \mathrm{~m}$ de profundidade. A calagem e adubação do solo foram feitas conforme a interpretação das recomendações do Boletim Técnico 100 (RAIJ et al., 1997) de acordo com a análise química. As análises química e física do solo foram realizadas no Departamento de Ciência do Solo da Faculdade de Ciências Agronômicas de Botucatu (Tabela 1 e 2).

Tabela 1. Análise química do solo da área experimental do Departamento de Engenharia Rural na profundidade de $0-0,20 \mathrm{~m}$.

\begin{tabular}{|c|c|c|c|c|c|c|c|c|c|}
\hline \multirow[t]{2}{*}{ Tipo } & \multirow{2}{*}{$\begin{array}{c}\mathrm{pH} \\
\mathrm{CaCl}^{2}\end{array}$} & \multirow{2}{*}{$\begin{array}{l}\text { M. O. } \\
\text { g dm }^{-3}\end{array}$} & $\mathrm{H}+\mathrm{A}$ & \multirow{2}{*}{\multicolumn{6}{|c|}{ 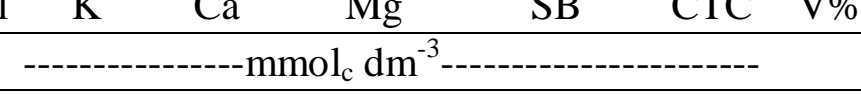 }} \\
\hline & & & & & & & & & \\
\hline Médio & 4,6 & 20 & 42 & 1,7 & 12 & 8 & 21 & 63 & 34 \\
\hline Tipo & BORO & $\mathrm{OCO}$ & BRE & FERRO & \multicolumn{2}{|c|}{ MANGANÊS } & ZINCO & $\mathrm{P}$ resina & \\
\hline \multicolumn{9}{|c|}{ 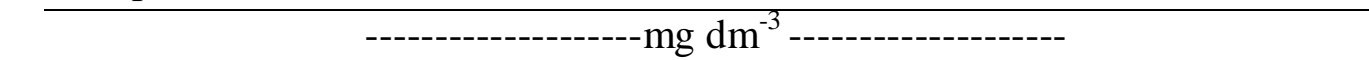 } & \\
\hline Médio & 0,23 & & 8 & 23 & & & 0,5 & 9 & \\
\hline
\end{tabular}


Tabela 2. Análise física do solo da área experimental do Departamento de Engenharia Rural na profundidade de $0-0,20 \mathrm{~m}$.

\begin{tabular}{rcccc}
\hline Tipo & Areia & Argila & Silte & Densidade \\
\hline \multicolumn{5}{c}{$\mathrm{g} \mathrm{kg}^{-1}$} \\
\hline Médio & 447 & 407 & 146 & 1,200 \\
\hline
\end{tabular}

A temperatura e a umidade relativa do ar foram observadas por meio de termômetros de máxima, bulbo seco e bulbo úmido (psicrômetro de ventilação natural) localizados dentro de abrigo meteorológico no interior da casa de vegetação (Figura 5).

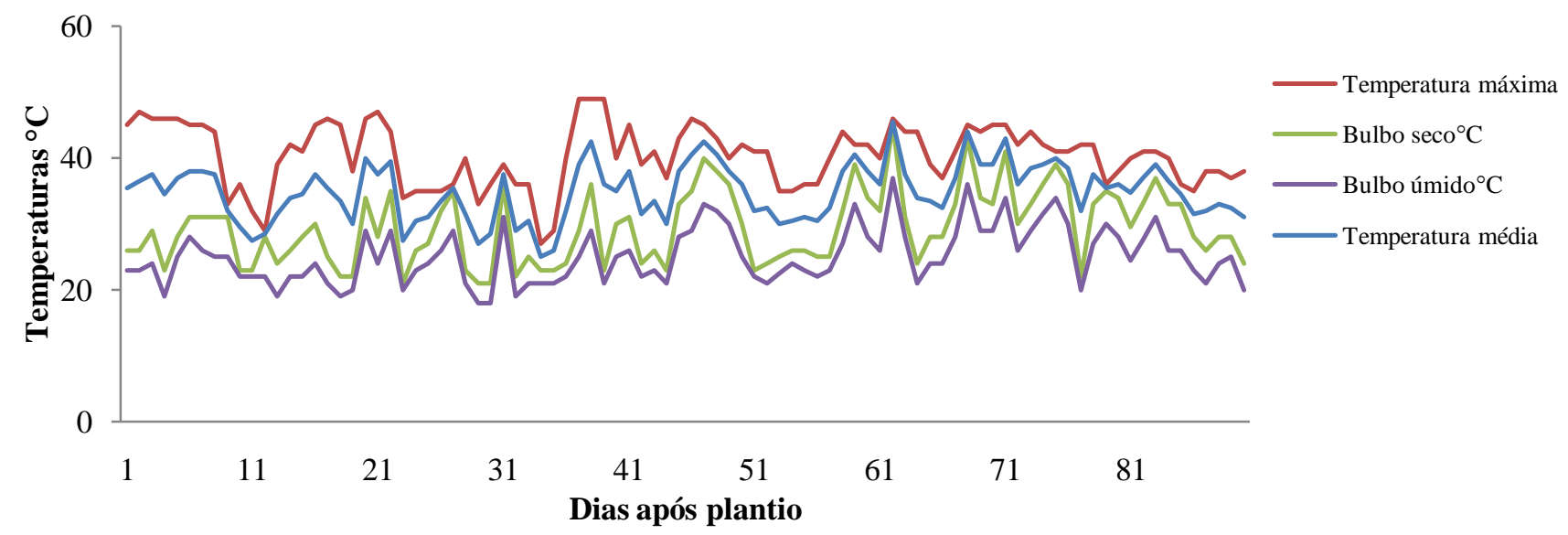

Figura 5. Temperatura máxima, temperatura do bulbo seco, temperatura do bulbo úmido e temperatura média dentro da casa de vegetação no período de 24/12/2008 a 23/03/2009.

Os dados de evaporação foram medidos diariamente por um tanque de $60 \mathrm{~cm}$ de diâmetro e 25,5 cm altura, localizado no interior da casa de vegetação, estimados pela equação 08, podem ser observados na Figura 6. 


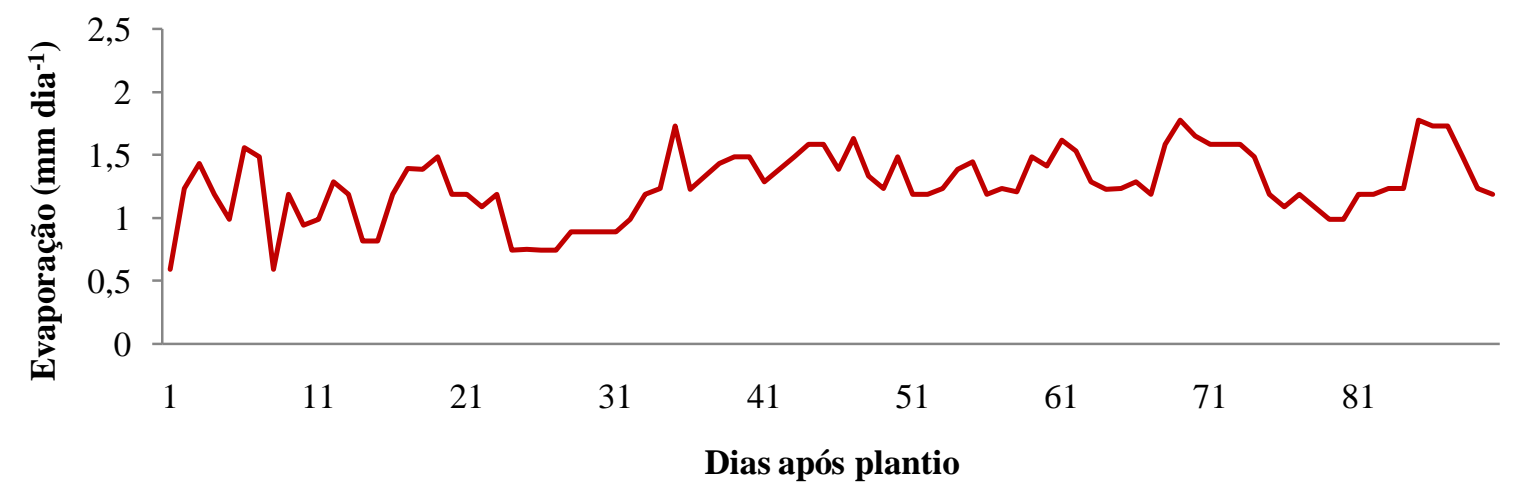

Figura 6. Evaporação do tanque dentro da casa de vegetação no período de 24/12/2008 a 23/03/2009.

A umidade relativa do ar foi obtida através das equações:

$$
e s=0,611 \times 10^{\frac{(7,5 T)}{(237,5+T)}}
$$

onde:

es = Pressão parcial de saturação à temperatura do termômetro úmido $(\mathrm{kPa})$;

$\mathrm{T}=$ Temperatura do bulbo seco.

$$
e a=e s-P \lambda(T a-T u)
$$

onde:

ea $=$ Pressão parcial atual de vapor de água do ar $(\mathrm{kPa})$;

$\lambda=0,0074 \mathrm{kPa}^{\circ} \mathrm{C}^{-1}$ (constante do psicrômetro com ventilação natural);

$\mathrm{Ta}=$ Temperatura do ar seco;

$\mathrm{Tu}=$ Temperatura do bulbo úmido;

$\mathrm{P}=$ Pressão atmosférica.

$$
P=760 *\left[1-\left(0,0065 * \frac{Z}{288}\right)\right]^{5,2568}
$$

onde:

$\mathrm{P}=$ Pressão atmosférica;

$\mathrm{Z}=$ Latitude local. 
Assim, a umidade relativa do ar será dada por:

$$
U R=\frac{e a}{e s} * 100
$$

onde:

$\mathrm{UR}=$ Umidade Relativa $(\%)$;

ea $=$ Pressão parcial atual de vapor de água do ar $(\mathrm{kPa})$;

es $=$ Pressão parcial de saturação à temperatura do termômetro úmido $(\mathrm{kPa})$;

A umidade relativa do ar dentro da casa de vegetação no período de 24 de dezembro de 2008 a 23 de março de 2009 estimada pela equação (04) está representada na Figura 7. Os maiores valores foram em torno de $70 \%$ e os menores valores foram em torno de $30 \%$.

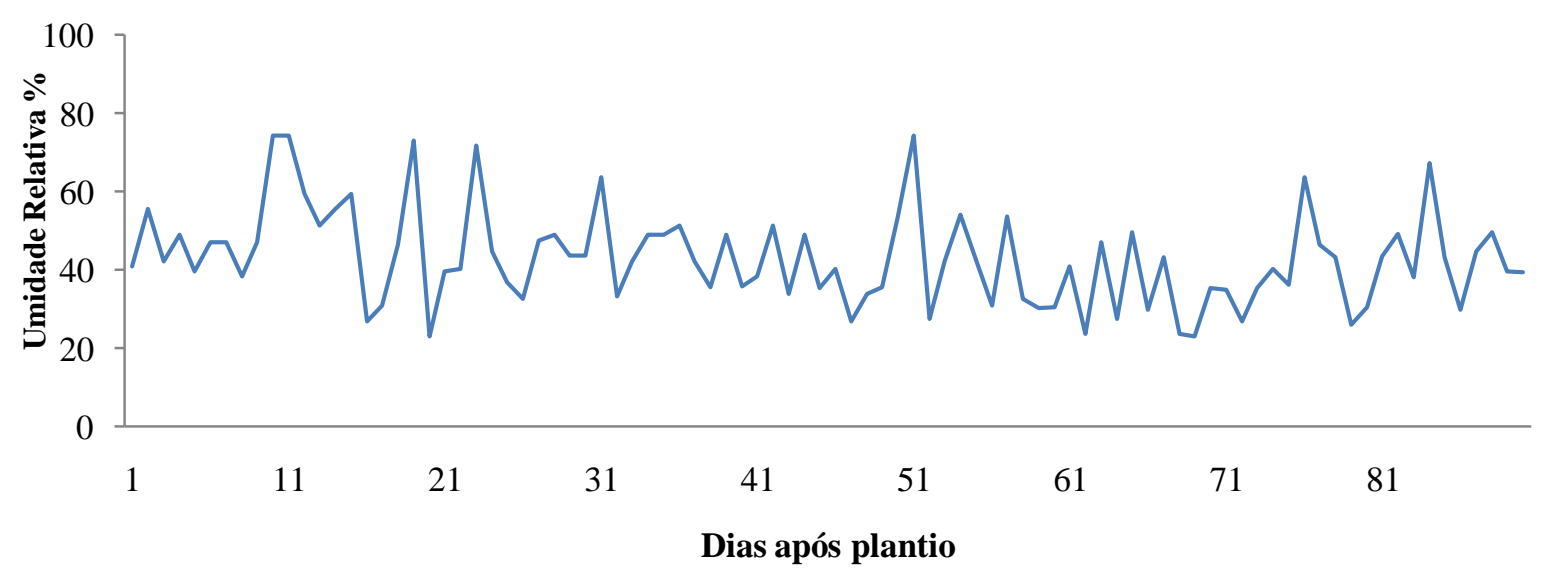

Figura 7. Umidade Relativa dentro da casa de vegetação no período de 24/12/2008 a 23/03/2009.

As respostas analisadas da cultura do sorgo, ao final do experimento, nos diferentes níveis de lençol freático foram: área foliar; número de folhas; massa da matéria fresca, seca, altura e diâmetro da base do colmo das plantas; massa da matéria seca total e particionada em camadas das raízes; massa da matéria fresca, seca e comprimento das panículas; evapotranspiração real da cultura (ETc), coeficiente da cultura (Kc) e eficiência do uso da água. 
Diversos são os métodos de estimativas de área foliar, destacando-se a utilização de equações que a relacionam com as dimensões lineares da folha. A área pode ser estimada através do produto entre o comprimento, a maior largura e um fator de ajuste. $\mathrm{O}$ fator de ajuste, ou fator de forma, varia com a cultura, situando-se ao redor de 0,7. Esse método, utilizado por Montgomery (1911), em milho, com fator igual a 0,75 , pode ser considerado como padrão para esta cultura (FRANCIS et al., 1969; PEARCE et al., 1975; MACHADO et al., 1982). Para a cultura do sorgo o fator utilizado nos cálculos foi de 0,747 (STICKLER et al, 1961). As medidas de comprimento e maior largura da folha foram realizadas ao final do experimento com a utilização de uma fita graduada.

Deste modo, estimou-se a área foliar das plantas conforme a equação:

$$
A F=0,747 C L
$$

Onde:

$\mathrm{AF}=$ área da folha $\left(\mathrm{cm}^{2}\right)$;

$\mathrm{C}=$ comprimento da folha $(\mathrm{cm})$;

$\mathrm{L}=$ maior largura da folha $(\mathrm{cm})$;

$0,747=$ coeficiente estabelecido para a cultura;

$$
A P=\sum_{i=1}^{n} A_{F i}
$$

Onde:

$\mathrm{AP}=$ área das folhas da planta $\left(\mathrm{cm}^{2}\right)$;

$\mathrm{AF}=$ área da folha $\left(\mathrm{cm}^{2}\right)$.

O número de folhas foi obtido pela contagem de todas as folhas das plantas ao final do experimento.

As plantas foram colhidas, logo após o florescimento aos 90 dias após plantio, foi determinada a massa da matéria fresca com a utilização de balança de precisão, comprimento utilizando-se de fita graduada em $\mathrm{mm}$ a partir do solo até a folha bandeira e diâmetro da base do colmo com a utilização de paquímetro digital e estas, secadas em estufa $\left(60-70^{\circ} \mathrm{C}\right)$ para a determinação da massa da matéria seca. Os tubos utilizados para o cultivo (vasos) foram desfeitos, camadas de $7 \mathrm{~cm}$, coletando-se uma amostra de solo para 
determinação do teor de água e, as raízes foram coletadas e postas para secar em estufa (60$\left.70^{\circ} \mathrm{C}\right)$ para a determinação da massa da matéria seca.

A evapotranspiração da cultura foi medida diariamente, no mesmo horário, com ajuda de fita graduada em milímetros localizada nos reservatórios, sendo determinada através da diferença entre a leitura de um dia com a leitura do dia seguinte, de acordo com a equação 07.

$$
E T c=(L x-L y) A r
$$

Onde:

ETc $=$ Evapotranspiração da cultura $\left(\mathrm{mm} \mathrm{dia}^{-1}\right)$;

$\mathrm{Lx}=$ leitura de um dia (mm);

$\mathrm{Ly}=$ leitura do dia posterior a $\mathrm{Lx}(\mathrm{mm})$.

$\mathrm{Ar}=$ Área do reservatório $\left(\mathrm{mm}^{2}\right)$

A evapotranspiração de referência foi medida com o uso de um tanque de $60 \mathrm{~cm}$ de diâmetro e $25,5 \mathrm{~cm}$ de altura localizado dentro da casa de vegetação e obtido através de estimativas de acordo com a equação 08 (OLIVEIRA, 2009), correlacionando os valores ao tanque classe $\mathrm{A}$. $\mathrm{O}$ valor de $\mathrm{Kp}$ utilizado foi 1 , utilizado em tanque classe $\mathrm{A}$ localizado dentro de casa de vegetação (PRADOS, 1986)

$$
\text { ETo }=(A+B) X K p
$$

Onde:

ETo = Evapotranspiração de referência $\left(\mathrm{mm} \mathrm{dia}^{-1}\right)$;

$\mathrm{A}=$ Coeficiente $\mathrm{A}(0,01871)$;

$\mathrm{B}=$ Coeficiente $\mathrm{B}(0,96957)$;

$\mathrm{X}=$ volume evaporado do tanque de $60 \mathrm{~cm}$ de diâmetro;

$\mathrm{Kp}=$ coeficiente do tanque (adimensional).

$r^{2}=0,97817$ 
O coeficiente da cultura $(\mathrm{Kc})$ foi obtido através da equação:

$$
K c=\frac{E T c}{E T o}
$$

Onde:

$\mathrm{Kc}=$ coeficiente da cultura (adimensional);

$\mathrm{ETc}=$ Evapotranspiração da cultura $\left(\mathrm{mm} \mathrm{dia}^{-1}\right)$;

ETo $=$ Evapotranspiração de referência $\left(\mathrm{mm} \mathrm{dia}^{-1}\right)$.

A avaliação da eficiência do uso da água foi feita através da produção de massa da matéria fresca, considerando que as plantas foram colhidas aos 90 dias (ciclo para forragem), em gramas, e a quantidade requerida de água durante o ciclo da cultura (água evapotranspirada dos vasos).

$$
E A=M F / E T C
$$

Onde:

$\mathrm{EA}=$ Eficiência do uso da água;

$\mathrm{MF}=$ massa da matéria fresca da planta $(\mathrm{g})$;

ETc $=$ Água evapotranspirada pela planta durante o ciclo $(\mathrm{mm})$.

A curva de retenção de água do solo (Tabela 3) foi obtida no Departamento de Engenharia Rural da Faculdade de Ciências Agronômicas de Botucatu.

Tabela 3. Relações entre os potenciais e os teores de água do solo.

\begin{tabular}{cc}
\hline $\begin{array}{c}\text { Potencial de água no solo } \\
(\mathrm{MPa})\end{array}$ & $\begin{array}{c}\text { Umidade volumétrica } \\
\left(\mathrm{cm}^{3} \mathrm{~cm}^{-3}\right)\end{array}$ \\
\hline 0 & 0,4500 \\
$-0,01$ & 0,2109 \\
$-0,03$ & 0,1788 \\
$-0,05$ & 0,1730 \\
$-0,3$ & 0,1498 \\
$-0,5$ & 0,1473 \\
$-1,5$ & 0,1472 \\
\hline
\end{tabular}


O delineamento experimental adotado foi o inteiramente casualizado, com seis tratamentos e 10 repetições, em um total de 60 vasos. O tratamento T6, lençol freático localizado a $87 \mathrm{~cm}$ de profundidade, foi desconsiderado, pois não houve emergência de plantas suficientes para as análises consideradas no trabalho. Os dados obtidos de massa da matéria fresca, massa da matéria seca, comprimento e diâmetro da parte aérea; massa da matéria seca das raízes; massa da matéria fresca, massa da matéria seca e comprimento das panículas, período de florescimento, área foliar e número de folhas foram submetidos à comparação de médias pelo teste Tukey ao nível de 5\% de probabilidade com o uso do programa Sisvar. 


\section{RESULTADOS E DISCUSSÃO}

4.1. Características agronômicas da cultura do sorgo em diferentes níveis freáticos.

A emergência das plântulas se iniciou em 27 de dezembro (4 dias após plantio) de 2008 e se estendeu até dia 04 de janeiro (12 dias após plantio) de 2009 como demonstra a Tabela 4. O desbaste ocorreu dia 12 de janeiro de 2009, deixando-se 2 plantas por vaso. Para que ocorresse a germinação das sementes dos tratamentos mais profundos (T3, T4, T5 e T6), foram adicionados $100 \mathrm{ml}$ de água todos os dias até que as plantas atingissem quatro

folhas expandidas. Observa-se na Tabela 4 que ocorreu diferenciação entre os tratamentos na germinação das sementes. Os tratamentos com maior quantidade de água disponível para as sementes emergiram antes que os demais. 
Tabela 4. Porcentagem de emergência das plântulas de sorgo (Sorghum bicolor L. Moench) submetidas a diferentes níveis de lençol freático, em casa de vegetação.

\begin{tabular}{lrrrrrrrrrr}
\hline \multirow{2}{*}{ Tratamentos } & \multicolumn{8}{c}{ Emergência das plântulas (\%) } & \multicolumn{2}{c}{ \% de } \\
& 4 DAP & 5 DAP & 6 DAP & 7 DAP & 8 DAP & 9 DAP & 10 DAP & 11 DAP & 12 DAP & Emergência \\
\hline T1 & 16 & 4 & 18 & 8 & 4 & 6 & 0 & 0 & 34 & 90 \\
T2 & 18 & 4 & 34 & 10 & 6 & 4 & 0 & 2 & 18 & 96 \\
T3 & 20 & 24 & 32 & 14 & 4 & 0 & 2 & 0 & 2 & 98 \\
T4 & 0 & 12 & 2 & 28 & 14 & 8 & 8 & 8 & 18 & 98 \\
T5 & 0 & 0 & 0 & 0 & 0 & 0 & 36 & 20 & 32 & 88 \\
T6 & 0 & 0 & 0 & 0 & 0 & 0 & 0 & 4 & 2 & 6 \\
\hline
\end{tabular}

Segundo Peters et al. (1982), a cultura do sorgo apresenta alguns problemas quanto à qualidade fisiológica das sementes que afetam o estande inicial, devido à desuniformidade de germinação. No entanto, não é este o caso, pois os demais tratamentos apresentaram boa germinação, em conformidade com os testes preliminares das sementes. $\mathrm{O}$ tratamento T6 $(87 \mathrm{~cm})$ não pôde ser considerado nas análises, pois não houve germinação de plantas suficientes (Tabela 4). A aplicação de $100 \mathrm{ml}$ de água diários mostrou-se insuficiente para este tratamento, o que não ocorreu nos demais, pois houve a necessária ascensão por capilaridade. Com o mesmo problema, o tratamento T5 $(73 \mathrm{~cm})$ iniciou a emergência aos 10 dias após o plantio e emergência de plântulas de 88\%. Alves et al. (1994) observaram que o diâmetro das colunas de solo (variando de 5 a $25 \mathrm{~cm}$ ), não influencia na ascensão capilar.

\subsubsection{Potencial matricial e umidade do solo}

A comparação das médias do potencial matricial do solo foi feita entre as camadas do tratamento e para cada altura entre os tratamentos. O componente do potencial matricial depende da umidade do solo e, por isso, o gradiente matricial depende da distribuição da umidade no perfil de solo (REICHARDT, 1990).

A relação entre o potencial matricial e a umidade do solo favorece uma avaliação rápida e precisa da disponibilidade de água no solo para as plantas (FREIRE, 1975; PAULETTO et al, 1988). Houve diferenças significativas entre as camadas de cada tratamento e entre os tratamentos (Tabela 5). 
Tabela 5. Potencial matricial ( - MPa), por camadas, a partir do nível de lençol freático à superfície do solo.

\begin{tabular}{lccccc}
\hline Camadas & $\mathrm{T} 1$ & $\mathrm{~T} 2$ & $\mathrm{~T} 3$ & $\mathrm{~T} 4$ & $\mathrm{~T} 5$ \\
\hline $67-74 \mathrm{~cm}$ & & & & & $5.10^{-1} \mathrm{C}$ \\
$60-67 \mathrm{~cm}$ & & & & & $2.10^{-1} \mathrm{~B}$ \\
$53-60 \mathrm{~cm}$ & & & & $2.10^{-1} \mathrm{Ba}$ & $1.10^{-2} \mathrm{ABb}$ \\
$46-53 \mathrm{~cm}$ & & & & $8.10^{-3} \mathrm{Aa}$ & $2.10^{-2} \mathrm{ABa}$ \\
$39-46 \mathrm{~cm}$ & & & $1.10^{-2} \mathrm{Ba}$ & $4.10^{-3} \mathrm{Aa}$ & $5.10^{-3} \mathrm{Aa}$ \\
$32-39 \mathrm{~cm}$ & & & $5.10^{-3} \mathrm{ABa}$ & $3.10^{-3} \mathrm{Ab}$ & $4.10^{-3} \mathrm{Aab}$ \\
$25-32 \mathrm{~cm}$ & & $2.10^{-3} \mathrm{Cc}$ & $4.10^{-3} \mathrm{ABa}$ & $2.10^{-3} \mathrm{Abc}$ & $3.10^{-3} \mathrm{Aab}$ \\
$18-25 \mathrm{~cm}$ & & $1.10^{-3} \mathrm{Cb}$ & $3.10^{-3} \mathrm{ABa}$ & $2.10^{-3} \mathrm{Ab}$ & $2.10^{-3} \mathrm{ACb}$ \\
$11-18 \mathrm{~cm}$ & $5.10^{-4} \mathrm{Ba}$ & $7.10^{-4} \mathrm{Ba}$ & $2.10^{-3} \mathrm{ABa}$ & $5.10^{-3} \mathrm{Aa}$ & $1.10^{-3} \mathrm{Aca}$ \\
$4-11 \mathrm{~cm}$ & $2.10^{-4} \mathrm{Ba}$ & $2.10^{-4} \mathrm{Aa}$ & $1.10^{-4} \mathrm{Aba}$ & $3.10^{-3} \mathrm{Aa}$ & $5.10^{-4} \mathrm{Aa}$ \\
$0-4 \mathrm{~cm}$ & $6.10^{-5} \mathrm{Ac}$ & $1.10^{-4} \mathrm{Abc}$ & $4.10^{-4} \mathrm{Aa}$ & $4.10^{-4} \mathrm{Aa}$ & $3.10^{-4} \mathrm{Aab}$ \\
\hline
\end{tabular}

*As médias seguidas da mesma letra maiúscula não se diferenciam nas colunas e, médias seguidas da mesma letra minúscula não se diferenciam nas linhas.

** CV $-49 ; 29 ; 206 ; 203 ; 195$ dos tratamentos T1; T2; T3; T4 e T5 respectivamente.

*** $\mathrm{F}-1,07 ; 1,27 ; 1,28 ; 7,72$ e 9,26 dos tratamentos $\mathrm{T} 1 ; \mathrm{T} 2 ; \mathrm{T} 3$; T4 e T5 respectivamente.

Os resultados de umidade do solo se encontram na Tabela 6. Em todos os tratamentos verificou-se diferenças significativas neste fator entre as camadas (anéis), diferenças estas, maiores nos tratamentos T4 e T5. Segundo a curva característica deste solo, a saturação deste solo se dá a $0,45 \mathrm{~cm}^{3} \mathrm{~cm}^{-3}$.

Tabela 6. Umidade do solo $\left(\mathrm{cm}^{3} \mathrm{~cm}^{-3}\right)$, por camadas, a partir do nível de lençol freático à superfície do solo.

\begin{tabular}{|c|c|c|c|c|c|}
\hline Camadas & $\mathrm{T} 1$ & $\mathrm{~T} 2$ & T3 & $\mathrm{T} 4$ & $\mathrm{~T} 5$ \\
\hline $67-74 \mathrm{~cm}$ & & & & & $0,1511 \mathrm{H}$ \\
\hline $60-67 \mathrm{~cm}$ & & & & & $0,1774 \mathrm{GH}$ \\
\hline $53-60 \mathrm{~cm}$ & & & & $0,1609 \mathrm{Fb}$ & $0,2125 \mathrm{Fa}$ \\
\hline $46-53 \mathrm{~cm}$ & & & & $0,2309 \mathrm{Ea}$ & $0,2290 \mathrm{Ea}$ \\
\hline $39-46 \mathrm{~cm}$ & & & $0,2464 \mathrm{Ca}$ & $0,2482 \mathrm{Da}$ & $0,2484 \mathrm{Da}$ \\
\hline $32-39 \mathrm{~cm}$ & & & $0,2477 \mathrm{Ca}$ & 0,2686 CDEa & $0,2652 \mathrm{Da}$ \\
\hline $25-32 \mathrm{~cm}$ & & $0,3185 \mathrm{Ca}$ & $0,2620 \mathrm{Cb}$ & $0,2869 \mathrm{BCDb}$ & $0,2793 \mathrm{CDb}$ \\
\hline $18-25 \mathrm{~cm}$ & & $0,3310 \mathrm{Ca}$ & $0,2858 \mathrm{BCb}$ & $0,3121 \quad \mathrm{Bab}$ & $0,3133 \mathrm{Bab}$ \\
\hline $11-18 \mathrm{~cm}$ & $0,3975 \mathrm{Ba}$ & 0,3786 Bab & $0,3173 \mathrm{Bc}$ & $0,3309 \mathrm{Bc}$ & $0,3418 \mathrm{Bbc}$ \\
\hline $4-11 \mathrm{~cm}$ & $0,4347 \mathrm{Ba}$ & $0,4328 \mathrm{Aa}$ & $0,3724 \mathrm{Ab}$ & 0,3927 Aab & 0,4034 Aab \\
\hline $0-4 \mathrm{~cm}$ & $0,4550 \mathrm{Aa}$ & $0,4391 \mathrm{Aab}$ & 0,4112 Ac & 0,4078 Ac & 0,4195 Abc \\
\hline
\end{tabular}

*As médias seguidas da mesma letra maiúscula não se diferenciam nas colunas e, médias seguidas da mesma letra minúscula não se diferenciam nas linhas.

** CV $-3,8 ; 4,7 ; 12 ; 11$ e 8,6 dos tratamentos T1; T2; T3; T4 e T5 respectivamente.

*** F-0,21;0,96; 6,39; 1,12 e 0,96 dos tratamentos T1; T2; T3; T4 e T5 respectivamente. 
4.1.2. Florescimento das plantas de sorgo submetidas a diferentes níveis de lençol freático em casa de vegetação.

A duração do florescimento das plantas de sorgo, considerando as 10 repetições, está representada na Tabela 7. A duração do florescimento ocorreu dos 8 aos 22 dias e ocorreu dos 62 aos 74 dias após o plantio. Os tratamentos T1 e T5 foram os mais tardios, iniciando seu florescimento aos 68 e 74 dias após plantio. O florescimento do tratamento T3 durou oito dias e o tratamento T1, 22 dias. $\mathrm{O}$ tratamento $\mathrm{T} 4$ foi o mais precoce, não diferenciando estatisticamente do T2 e T3, iniciando o florescimento aos 62 dias após plantio e a duração do florescimento foi de 16 dias. Estes resultados estão de acordo com Magalhães e Durães (2003), a duração do florescimento varia de 6 a 15 dias e ocorre dos 60 aos 82 dias após o plantio.

Tabela 7. Período de florescimento das plantas de sorgo (Sorghum bicolor L. Moench) submetidas a diferentes níveis de lençol freático, em casa de vegetação.

\begin{tabular}{lccc}
\hline Tratamento & $\begin{array}{c}\text { Florescimento (DAP) } \\
\text { Início }\end{array}$ & $\begin{array}{c}\text { Duração } \\
\text { (dias) }\end{array}$ \\
\hline $\mathrm{T} 1$ & 68 & $89 \mathrm{bc}$ & 22 \\
$\mathrm{~T} 2$ & 69 & $83 \mathrm{ab}$ & 14 \\
$\mathrm{~T} 3$ & 64 & $72 \mathrm{a}$ & 8 \\
$\mathrm{~T} 4$ & 62 & $78 \mathrm{a}$ & 16 \\
$\mathrm{~T} 5$ & 74 & $89 \mathrm{c}$ & 15 \\
$\mathrm{CV}-4,04$ & $\mathrm{~F}-12,947$ & &
\end{tabular}

4.1.3. Massa da matéria fresca e seca da parte aérea das plantas de sorgo.

As médias de massa da matéria fresca e seca da parte aérea das plantas de sorgo foram submetidas à análise estatística, teste Tukey a 5\%, e observa-se, na Figura 8. diferença entre os tratamentos, sendo os tratamentos T4 (137,3 g) e T5 (131,5 g) obtiveram significativamente as maiores massas da matéria fresca de plantas e, os tratamentos T1 (89,4 g) e T2 (31 g) obtiveram as menores, o que deve ter sido causado pelo menor volume de raízes desenvolvidas pelas plantas devido a influência do nível freático. O tratamento T3 não se diferenciou estatisticamente dos demais, tanto na massa fresca quanto na massa seca das 
plantas. O tratamento T4 $(64,01 \mathrm{~g})$ apresentou estatisticamente a maior massa seca da parte aérea em relação aos tratamentos T5 $(41,07 \mathrm{~g})$, T1 (37,52g) e T2 (36,25g), os menores.

Em relação aos tratamentos $\mathrm{T} 1$ e $\mathrm{T} 2$ estes resultados corroboram com os encontrados por Barreto et al. (2008), trabalhando com sorgo forrageiro, observaram diminuição na produção de matéria fresca e seca das plantas, quando estas eram submetidas ao alagamento. No T5 as plantas começaram a acompanhar os demais tratamentos mesmo com o atraso em receber água do lençol freático (Tabela 4). Este tratamento também mostrou algumas discrepâncias em relação à altura (Figura 9), acompanhando a massa seca (Figura 8), área foliar e número de folhas (Figuras 11 e 12) com dados significativamente menores que as do T4, porém apresentou diâmetros do colmo (Figura 10) mais elevados em relação aos T1 e $\mathrm{T} 2$.

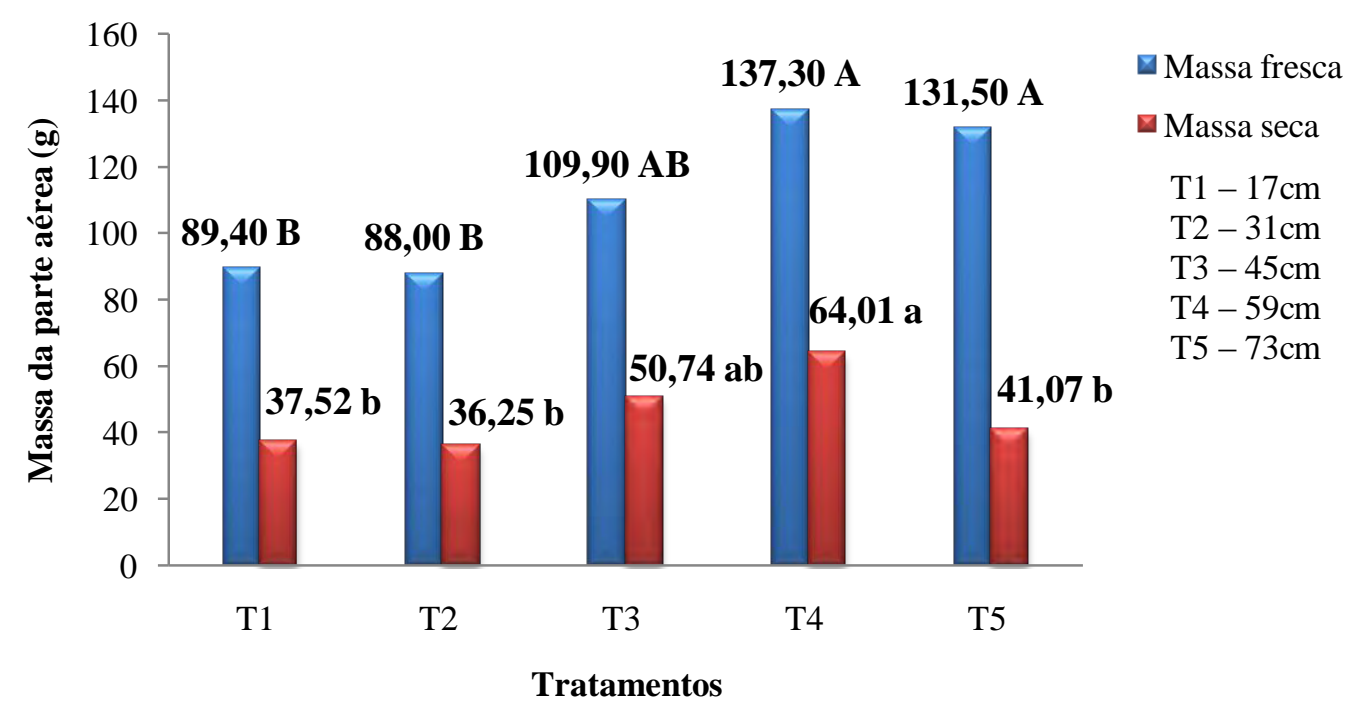

*CV - 26,58; 33,41 - Massa fresca e massa seca respectivamente;

** $\mathrm{F}-0,53 ; 1,91$ - Massa fresca e massa seca respectivamente.

Figura 8. Massa fresca e seca da parte aérea, em gramas, das plantas de sorgo (Sorghum bicolor L. Moench) submetidas aos diferentes níveis de lençol freático, pelo Teste Tukey a 5\% de probabilidade. 


\subsubsection{Altura e diâmetro das plantas de sorgo}

Não foram observadas diferenças significativas quanto à altura das plantas de sorgo, em cm, como mostra a Figura 9. As maiores médias foram encontradas nos tratamentos $\mathrm{T} 4(133,80 \mathrm{~cm})$ e $\mathrm{T} 3(130,55 \mathrm{~cm})$. A altura das plantas foi próxima às características descritas para a cultivar Catissorgo que é de 140cm (CATI, 2009).

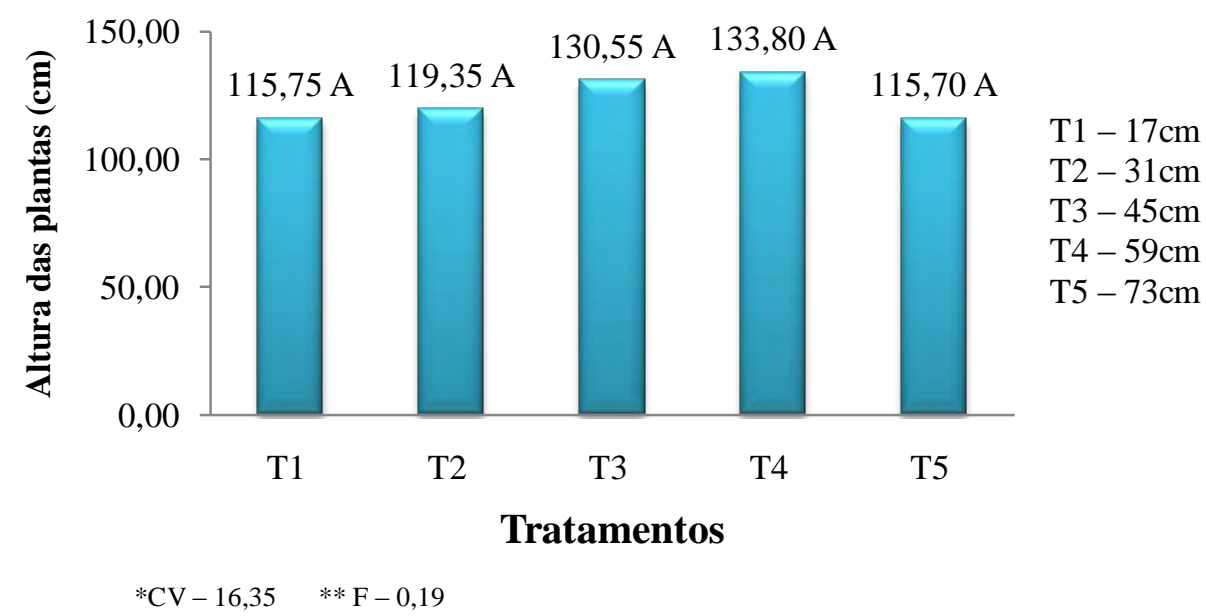

Figura 9. Altura das plantas de sorgo (Sorghum bicolor L. Moench), em $\mathrm{cm}$, submetidas a diferentes níveis de lençol freático, pelo teste Tukey a 5\% de probabilidade.

As médias dos diâmetros do colmo, em mm, obtidas na base das plantas, apresentaram diferenças significativas, como se pode observar na Figura 10. O diâmetro do tratamento T5 $(15,15 \mathrm{~mm})$ foi o maior, não diferenciando significativamente de T4 (14,65 mm) e T3 (13,20 mm), porém se diferenciando dos demais. O tratamento T4, T3 e T1 (12,50 mm) não se diferenciam entre si e os tratamentos T1, T2 (12,20 mm) e T3 não se diferenciam, mesmo assim, houve uma tendência dos tratamentos T4 e T5 apresentarem valores maiores que os demais. 


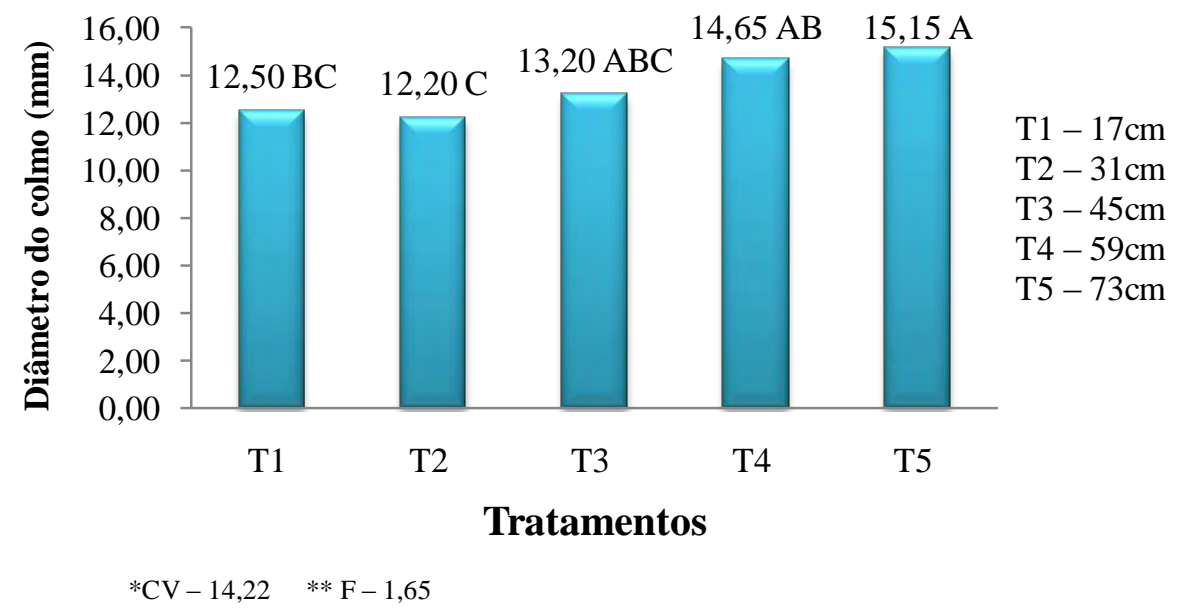

Figura 10. Diâmetro do colmo (mm) das plantas de sorgo (Sorghum bicolor L. Moench) submetidas a diferentes níveis de lençol freático, pelo teste Tukey a 5\% de probabilidade.

A Figura 11 demonstra a área foliar, estimada pelas equações 05 e 06, variando de $1587,23 \mathrm{~cm}^{2}$ a $865,32 \mathrm{~cm}^{2}$ por planta e, a Figura 12 demonstra o número de folhas variando de 6,6 a 4,2 folhas por planta. Segundo Magalhães e Durães (2003), o número de folhas varia de 7 a 14 e a área foliar varia de 37,5 a $1125 \mathrm{~cm}^{2}$. A área foliar dos tratamentos T4 foi a maior média, não diferindo significativamente de T2 e T3. Os tratamentos T1 e T5 apresentaram as menores médias e diferiram significativamente de $\mathrm{T} 4$, mas não diferiram de T1 e T5.

Em relação a estes resultados, o tratamento $\mathrm{T} 1$ se desenvolveu sob condições de excesso de água afetando o desenvolvimento das plantas, produzindo as menores massas de matéria fresca e seca, uma das menores altura de plantas, um dos menores diâmetros de colmo e a menor área foliar. O tratamento T5, ao contrário, se desenvolveu sob menores quantidades de água como pode se observar na Tabela 6 .

Quanto ao número de folhas, o tratamento T4 foi o maior valor se diferindo significativamente dos demais (Figura 12). 


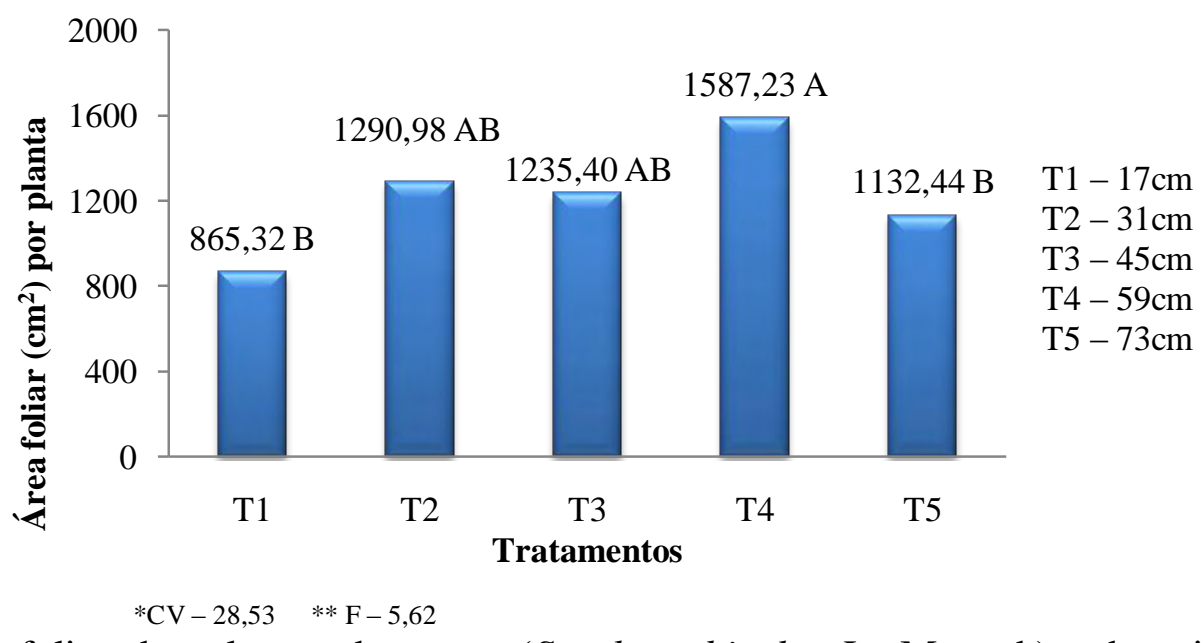

Figura 11. Área foliar das plantas de sorgo (Sorghum bicolor L. Moench) submetidas a diferentes níveis de lençol freático.

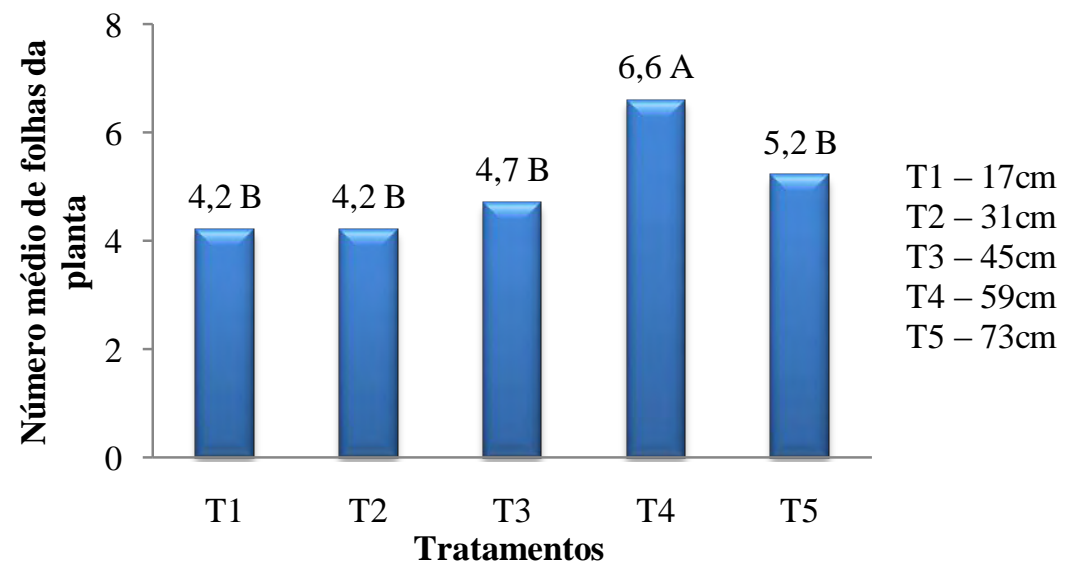

${ }^{*} \mathrm{CV}-18,28 \quad{ }^{*} * \mathrm{~F}-11,97$

Figura 12. Número de folhas das plantas de sorgo (Sorghum bicolor L. Moench) submetidas a diferentes níveis de lençol freático.

4.1.5. Massa da matéria seca das raízes: total e particionada em camadas $(7 \mathrm{~cm})$.

O tratamento T1 (11,46 g) foi o único que apresentou diferenças na comparação das médias da massa da matéria seca total das raízes das plantas no teste Tukey a 5\% de significância (Figura 13), pois o tratamento T1 havia somente $17 \mathrm{~cm}$ acima do lençol freático, o que restringiu o desenvolvimento das raízes. 


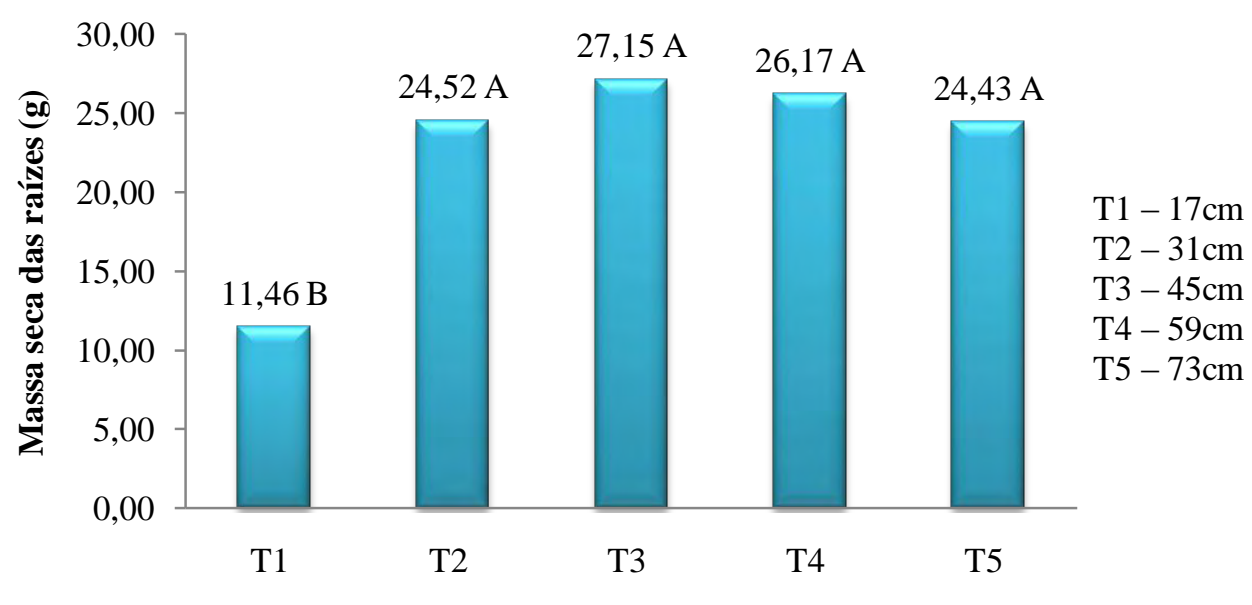

Tratamentos

${ }^{*} \mathrm{CV}-37,12 * * \mathrm{~F}-2,74$

Figura 13. Massa da matéria seca total das raízes, em gramas, das plantas de sorgo (Sorghum bicolor L. Moench) submetidas a diferentes níveis de lençol freático, pelo teste Tukey a 5\% de probabilidade.

A massa da matéria seca das raízes também foi feita por camadas de 7 $\mathrm{cm}$ nos tratamentos (Tabela 8). Na primeira camada $(0-4 \mathrm{~cm})$ foram consideradas as raízes adventícias de fixação, apresentando assim, valores de duas a três vezes maiores que a camada seguinte. Não houve diferenças no anel que se encontrava de 4 a $11 \mathrm{~cm}$; dos 18 aos $25 \mathrm{~cm}$ e dos 39 aos $46 \mathrm{~cm}$ da superfície dos tratamentos. Em todas as outras análises foi observada diferença entre os tratamentos e entre o desenvolvimento das raízes nas diferentes profundidades. A quantidade de raízes diminuía de acordo com a profundidade analisada nos tratamentos. A profundidade do sistema radicular do sorgo, em condições de campo, chega até $1,5 \mathrm{~m}$ e se diferencia em quantidade no perfil do solo com maior volume próximo à superfície do solo (MAGALHÃES et al, 2003). 
Tabela 8. Massa da matéria seca das raízes de sorgo (Sorghum bicolor L. Moench) particionadas nas diferentes profundidades do solo $(7 \mathrm{~cm})$ nos diferentes níveis de lençol freático.

\begin{tabular}{|c|c|c|c|c|c|}
\hline Profundidade & $\mathrm{T} 1$ & $\mathrm{~T} 2$ & T3 & $\mathrm{T} 4$ & T5 \\
\hline $0-7 \mathrm{~cm}$ & $8,19 \mathrm{Abc}$ & $12,60 \mathrm{Aa}$ & $11,59 \mathrm{Aab}$ & $11,25 \mathrm{Aab}$ & $6,72 \mathrm{Ac}$ \\
\hline $7-14 \mathrm{~cm}$ & $2,51 \mathrm{Ba}$ & $4,67 \mathrm{Ba}$ & $4,03 \mathrm{Ba}$ & 4,93 $\mathrm{Ba}$ & $3,68 \mathrm{Ba}$ \\
\hline $14-21 \mathrm{~cm}$ & $0,76 \mathrm{Cb}$ & 2,90 Bab & 2,24 BCab & $2,58 \mathrm{Cab}$ & $3,56 \mathrm{Ba}$ \\
\hline $21-28 \mathrm{~cm}$ & & $2,90 \mathrm{Ba}$ & $2,87 \mathrm{Ba}$ & $1,63 \mathrm{Ca}$ & $2,49 \mathrm{Ba}$ \\
\hline $28-35 \mathrm{~cm}$ & & $1,46 \mathrm{Bb}$ & $2,77 \mathrm{Ba}$ & $1,19 \mathrm{Cb}$ & 2,24 $\mathrm{Bab}$ \\
\hline $35-42 \mathrm{~cm}$ & & & $2,45 \mathrm{Ba}$ & $1,52 \mathrm{Cab}$ & $1,38 \mathrm{Cb}$ \\
\hline $42-49 \mathrm{~cm}$ & & & $1,21 \mathrm{Ca}$ & $1,21 \mathrm{Ca}$ & $1,08 \mathrm{Ca}$ \\
\hline $49-56 \mathrm{~cm}$ & & & & $1,37 \mathrm{Ca}$ & $0,78 \mathrm{Ca}$ \\
\hline $56-63 \mathrm{~cm}$ & & & & $0,47 \mathrm{Cb}$ & $1,03 \mathrm{Ca}$ \\
\hline $63-70 \mathrm{~cm}$ & & & & & $0,95 \mathrm{C}$ \\
\hline $70-73 \mathrm{~cm}$ & & & & & $0,52 \mathrm{C}$ \\
\hline
\end{tabular}

*As médias seguidas da mesma letra maiúscula não se diferenciam nas colunas e, médias seguidas da mesma letra minúscula não se diferenciam nas linhas.

** CV - 36,6; 66,1; 39,2; 56 e 72,5 dos tratamentos T1; T2; T3; T4 e T5 respectivamente.

*** F-6,61;2,35; 1,$98 ; 8,95$ e 2,84 dos tratamentos $\mathrm{T} 1 ; \mathrm{T} 2$; T3; T4 e T5 respectivamente.

Com base na curva característica do solo, a porcentagem de ar e a porcentagem de água puderam ser estimadas (Tabela 9). Correlacionando as tabelas 8 e 9, os dados apresentados em itálico demonstram que aproximadamente $80 \%$ do sistema radicular se encontravam nos primeiros $30 \mathrm{~cm}$ de profundidade (Tabela 10). Magalhães et al (2003), em sorgo, também considera este valor. Possivelmente nesta camada existia as melhores condições para o desenvolvimento radicular, pois Klar (1984) descreveu que um solo com ótimas condições para o crescimento vegetal contém cerca de $50 \%$ de espaço poroso (25\% de água e $25 \%$ de ar) e $50 \%$ de sólidos. 
Tabela 9. Porcentagem de ar e água nas diferentes profundidades $(7 \mathrm{~cm})$ em cada nível de lençol freático.

\begin{tabular}{|c|c|c|c|c|c|c|c|c|c|c|}
\hline \multirow{2}{*}{ Profundidade } & \multicolumn{2}{|c|}{$\mathrm{T} 1$} & \multicolumn{2}{|c|}{$\mathrm{T} 2$} & \multicolumn{2}{|c|}{ T3 } & \multicolumn{2}{|c|}{ T4 } & \multicolumn{2}{|c|}{ T5 } \\
\hline & $\%$ ar & $\%$ água & $\%$ ar & \% água & $\%$ ar & $\%$ água & $\%$ ar & $\%$ água & $\%$ ar & $\%$ água \\
\hline $0-7 \mathrm{~cm}$ & 11,66 & 88,34 & 29,22 & 70,78 & 45,23 & 54,77 & 64,24 & 35,76 & 66,43 & 33,57 \\
\hline $7-14 \mathrm{~cm}$ & 3,39 & 96,61 & 26,45 & 73,55 & 44,95 & 55,05 & 48,69 & 51,31 & 60,57 & 39,43 \\
\hline $14-21 \mathrm{~cm}$ & 0,00 & 100,00 & 15,86 & 84,14 & 41,78 & 58,22 & 44,84 & 55,16 & 52,77 & 47,23 \\
\hline $21-28 \mathrm{~cm}$ & & & 3,82 & 96,18 & 36,49 & 63,51 & 40,32 & 59,68 & 49,12 & 50,88 \\
\hline $28-35 \mathrm{~cm}$ & & & 2,43 & 97,57 & 29,49 & 70,51 & 36,24 & 63,76 & 44,81 & 55,19 \\
\hline $35-42 \mathrm{~cm}$ & & & & & 17,25 & 82,75 & 30,65 & 69,35 & 41,07 & 58,93 \\
\hline $42-49 \mathrm{~cm}$ & & & & & 8,61 & 91,39 & 26,47 & 73,53 & 37,92 & 62,08 \\
\hline $49-56 \mathrm{~cm}$ & & & & & & & 12,73 & 87,27 & 30,38 & 69,62 \\
\hline $56-63 \mathrm{~cm}$ & & & & & & & 9,37 & 90,63 & 24,79 & 75,21 \\
\hline $63-70 \mathrm{~cm}$ & & & & & & & & & 9,66 & 90,34 \\
\hline $70-73 \mathrm{~cm}$ & & & & & & & & & 7,27 & 92,73 \\
\hline
\end{tabular}

Tabela 10. Porcentagem da quantidade de raízes de sorgo (Sorghum bicolor L. Moench) nas diferentes profundidades $(7 \mathrm{~cm})$ nos diferentes níveis de lençol freático.

\begin{tabular}{lrrrrr}
\hline Profundidade & \multicolumn{1}{c}{ T1 } & \multicolumn{1}{c}{ T2 } & \multicolumn{1}{c}{ T3 } & \multicolumn{1}{c}{ T4 } & \multicolumn{1}{c}{ T5 } \\
\hline $0-7 \mathrm{~cm}$ & 71,60 & 53,09 & 43,62 & 43,52 & 30,19 \\
$7-14 \mathrm{~cm}$ & 21,83 & 16,11 & 14,30 & 18,47 & 14,49 \\
$14-21 \mathrm{~cm}$ & 6,58 & 10,69 & 8,24 & 9,67 & 13,21 \\
$21-28 \mathrm{~cm}$ & & 12,42 & 10,31 & 6,49 & 9,87 \\
$28-35 \mathrm{~cm}$ & & 7,70 & 9,77 & 4,48 & 10,12 \\
$35-42 \mathrm{~cm}$ & & & 9,08 & 5,72 & 5,54 \\
$42-49 \mathrm{~cm}$ & & & 4,68 & 4,71 & 3,92 \\
$49-56 \mathrm{~cm}$ & & & & 5,09 & 2,90 \\
$56-63 \mathrm{~cm}$ & & & & 1,86 & 3,90 \\
$63-70 \mathrm{~cm}$ & & & & & 3,71 \\
$70-73 \mathrm{~cm}$ & & & & & 2,15 \\
\hline
\end{tabular}


4.1.6. Massa da matéria fresca, massa da matéria seca e comprimento das panículas.

$\mathrm{O}$ tratamento $\mathrm{T} 1 \quad(8,17 \mathrm{~g})$ se diferenciou significativamente dos tratamentos T4 (19,71 g) e T5 (17,95 g) na comparação de médias da massa fresca das panículas pelo teste Tukey (Figura 14), e apresentou a menor média, justamente por estar sob condições desfavoráveis ao seu desenvolvimento, conforme salientado anteriormente.

Os tratamentos T3 (13,28 g) e T2 (12,77 g) não se diferenciaram dos outros tratamentos. As maiores médias foram de T4 (19,71 g) e T5 (17,95 g). A massa da matéria seca das panículas segue a tendência da massa da matéria fresca, exceto o T5 em que, em média, perdeu mais água que o tratamento T3, contudo, não se diferenciando do T4 que foi a maior massa da matéria fresca e seca em média.

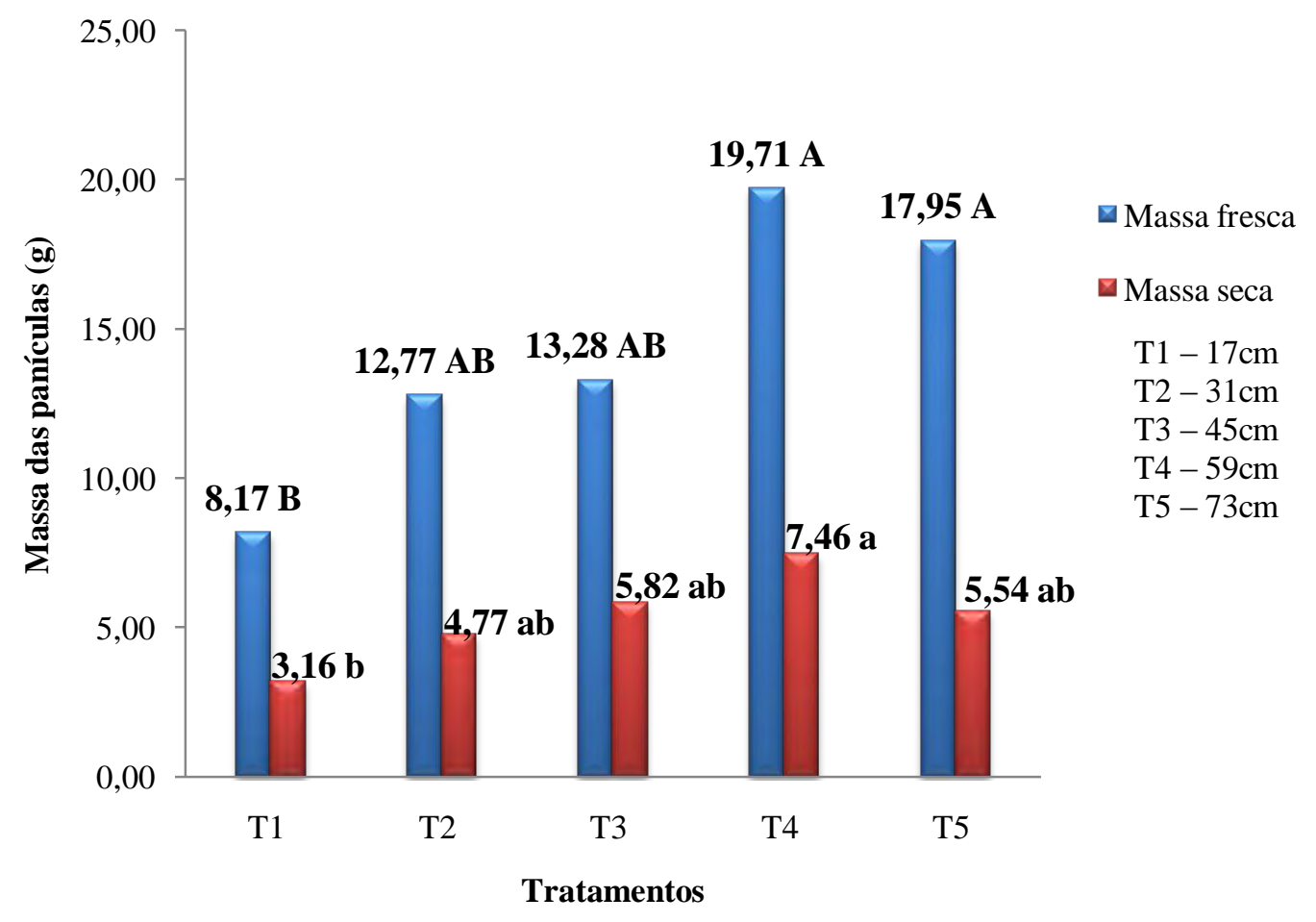

$* \mathrm{CV}-45,07 ; 44,53$ - Massa fresca e massa seca respectivamente;

** $\mathrm{F}-3,31 ; 2,46$ - Massa fresca e massa seca respectivamente.

Figura 14. Massa fresca e seca das panículas, em gramas, de sorgo (Sorghum bicolor L. Moench) submetidas a diferentes níveis de lençol freático, pelo teste Tukey a 5\% de significância. 
Ocorreu diferença entre os tratamentos quanto ao comprimento das panículas (Figura 15), sendo T5 $(25,57 \mathrm{~cm})$, T4 $(23,97 \mathrm{~cm})$ as maiores médias e T1 $(17,85 \mathrm{~cm})$ e T2 $(18,97 \mathrm{~cm})$ as menores. O T3 não se diferenciou estatisticamente de nenhum dos tratamentos. Segundo Magalhães e Durães (2003) o comprimento das panículas varia de 4 a $25 \mathrm{~cm}$. Neste estádio de desenvolvimento da cultura, as plantas do T5 tinham disponibilidade de água favoráveis ao desenvolvimento das panículas. A produção de grãos não pôde ser estimada, pois as plantas foram colhidas antes da maturação, assim sendo, algumas plantas apresentavam panículas em início de formação.

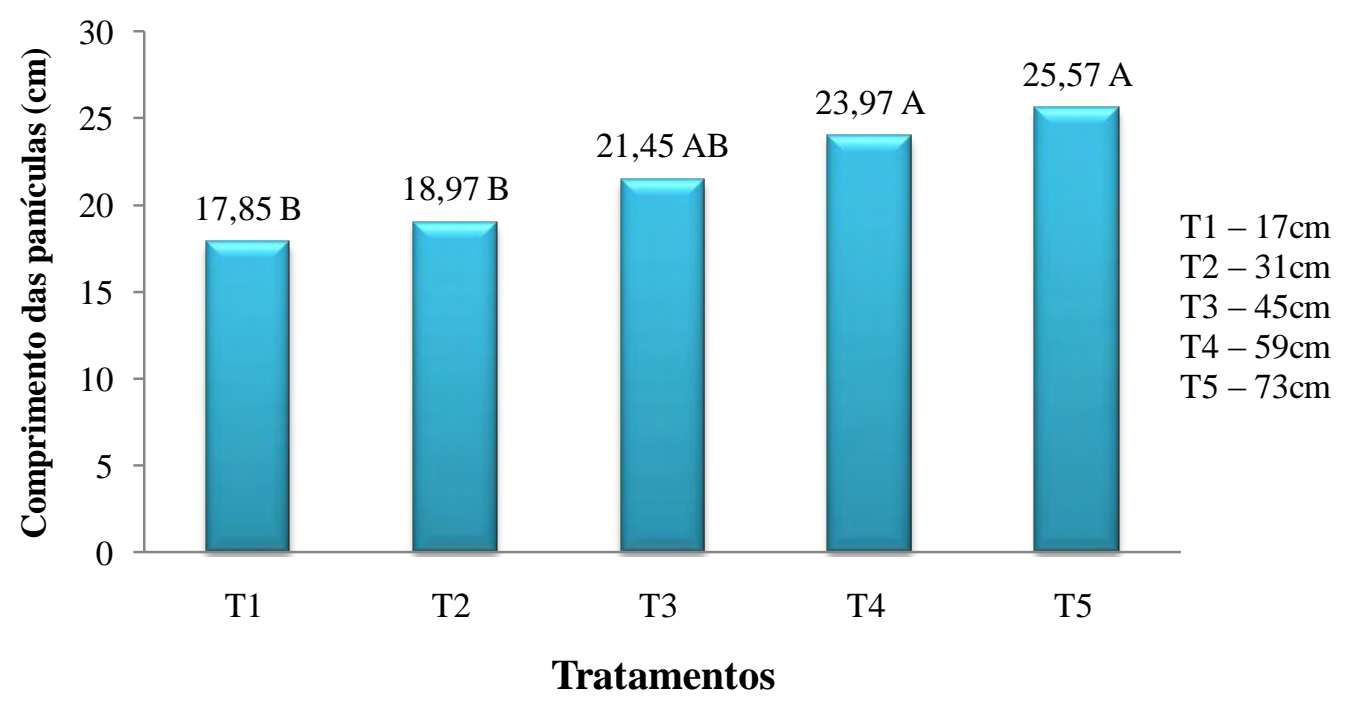

${ }^{*} \mathrm{CV}-15,06 \quad * * \mathrm{~F}-3,14$

Figura 15. Comprimento das panículas $(\mathrm{cm})$ das plantas de sorgo (Sorghum bicolor L. Moench) submetidas a diferentes níveis de lençol freático, pelo teste Tukey a 5\% de probabilidade. 
4.2. Evapotranspiração da cultura do sorgo em diferentes níveis freáticos e eficiência do uso da água.

A evapotranspiração da cultura (ETc), estimada pela equação 07, a evapotranspiração de referência (ETo), estimada pela equação 08, e o coeficiente da cultura (Kc), estimado pela equação 09, foram medidas diariamente para todos os níveis de lençol freático e estão apresentados com valores decendiais na Tabela 11 . Os valores de evapotranspiração da cultura variaram de $115 \mathrm{~mm}$ a $184,58 \mathrm{~mm}$.

Tabela 11. Evapotranspiração de referência (ETo), evapotranspiração da cultura (ETc) decendiais e coeficiente da cultura $(\mathrm{Kc})$ médio decendial da cultura do sorgo (Sorghum bicolor L. Moench) submetidas a diferentes níveis de lençol freático.

\begin{tabular}{|c|c|c|c|c|c|c|c|c|c|c|}
\hline \multirow{2}{*}{ Tratamentos } & \multicolumn{9}{|c|}{ Dias após plantio } & \multirow{2}{*}{$\begin{array}{c}\text { Total do } \\
\text { ciclo }\end{array}$} \\
\hline & 01 a 10 & 11 a 20 & 21 a 30 & 31 a 40 & 41 a 50 & 51 a 60 & 61 a 70 & 71 a 8( & 81 a 90 & \\
\hline \multicolumn{11}{|c|}{ T1 $(17 \mathrm{~cm})$} \\
\hline Etc (mm) & 7,95 & 9,22 & 8,05 & 8,40 & 21,73 & 24,09 & 26,11 & 26,58 & 20,68 & 152,82 \\
\hline Eto (mm) & 10,25 & 11,47 & 9,40 & 12,39 & 14,38 & 13,03 & 14,14 & 13,41 & 13,79 & 112,26 \\
\hline $\mathrm{Kc}$ & & 0,5 & & & & & 1,41 & & & \\
\hline \multicolumn{11}{|c|}{ J } \\
\hline Etc (mm) & 4,57 & 6,02 & 6,52 & 7,34 & 19,37 & 16,85 & 20,67 & 17,91 & 15,75 & 115,00 \\
\hline Eto $(\mathrm{mm})$ & 10,25 & 11,47 & 9,40 & 12,39 & 14,38 & 13,03 & 14,14 & 13,41 & 13,79 & 112,26 \\
\hline $\mathrm{Kc}$ & & 0,5 & & & & & 1,52 & & & \\
\hline \multicolumn{11}{|c|}{$5(4$} \\
\hline Etc $(\mathrm{mm})$ & 8,61 & 7,79 & 11,14 & 10,06 & 30,19 & 25,82 & 37,88 & 36,94 & 16,15 & 184,58 \\
\hline Eto $(\mathrm{mm})$ & 10,25 & 11,47 & 9,40 & 12,39 & 14,38 & 13,03 & 14,14 & 13,41 & 13,79 & 112,26 \\
\hline $\mathrm{Kc}$ & & 0,5 & & & & & 1,52 & & & \\
\hline \multicolumn{11}{|c|}{ T4(5) } \\
\hline Etc $(\mathrm{mm})$ & 2,83 & 2,99 & 5,01 & 5,35 & 22,28 & 29,43 & 38,73 & 41,35 & 22,42 & 170,38 \\
\hline Eto (mm) & 10,25 & 11,47 & 9,40 & 12,39 & 14,38 & 13,03 & 14,14 & 13,41 & 13,79 & 112,26 \\
\hline $\mathrm{Kc}$ & & 0,4 & & & & & 1,48 & & & \\
\hline \multicolumn{11}{|c|}{$5(73 \mathrm{~cm})$} \\
\hline Etc (mm) & 3,12 & 1,65 & 2,14 & 2,71 & 10,22 & 14,17 & 24,90 & 33,22 & 29,77 & 121,91 \\
\hline Eto (mm) & 10,25 & 11,47 & 9,40 & 12,39 & 14,38 & 13,03 & 14,14 & 13,41 & 13,79 & 112,26 \\
\hline $\mathrm{Kc}$ & \multicolumn{3}{|c|}{0,38} & \multicolumn{7}{|c|}{1,51} \\
\hline
\end{tabular}


O coeficiente da cultura $(\mathrm{Kc})$ correlaciona o consumo de água específico da planta em determinado estádio de desenvolvimento. O Kc inicial dos tratamentos variou de 0,38 a 0,56 e o Kc médio variou de 1,41 a 1,52, valores estes superiores aos apresentados pela FAO que são de 0,3 e 1,15 respectivamente (DOORENBOS, 1979). As condições de clima na casa de vegetação, cultivar e solo devem ser as razões da discrepância entre os resultados e os dados indicados por aqueles autores.

A eficiência do uso da água foi estimada pela equação 10 e está representada na Figura 16. As plantas de sorgo submetidas ao lençol freático mais profundo, $\mathrm{T} 5$, produziram mais matéria fresca por mm de água utilizada, seguida pelo tratamento T4. As plantas menos eficientes foram as do tratamento T1 e T3. Observa-se que há grande elasticidade no consumo, que varia com as condições de solo, variedade e clima. A análise estatística não foi possível, pois os vasos estavam dispostos em duas bandejas, não tendo assim o mínimo de repetições necessárias para esta análise por tratamento.

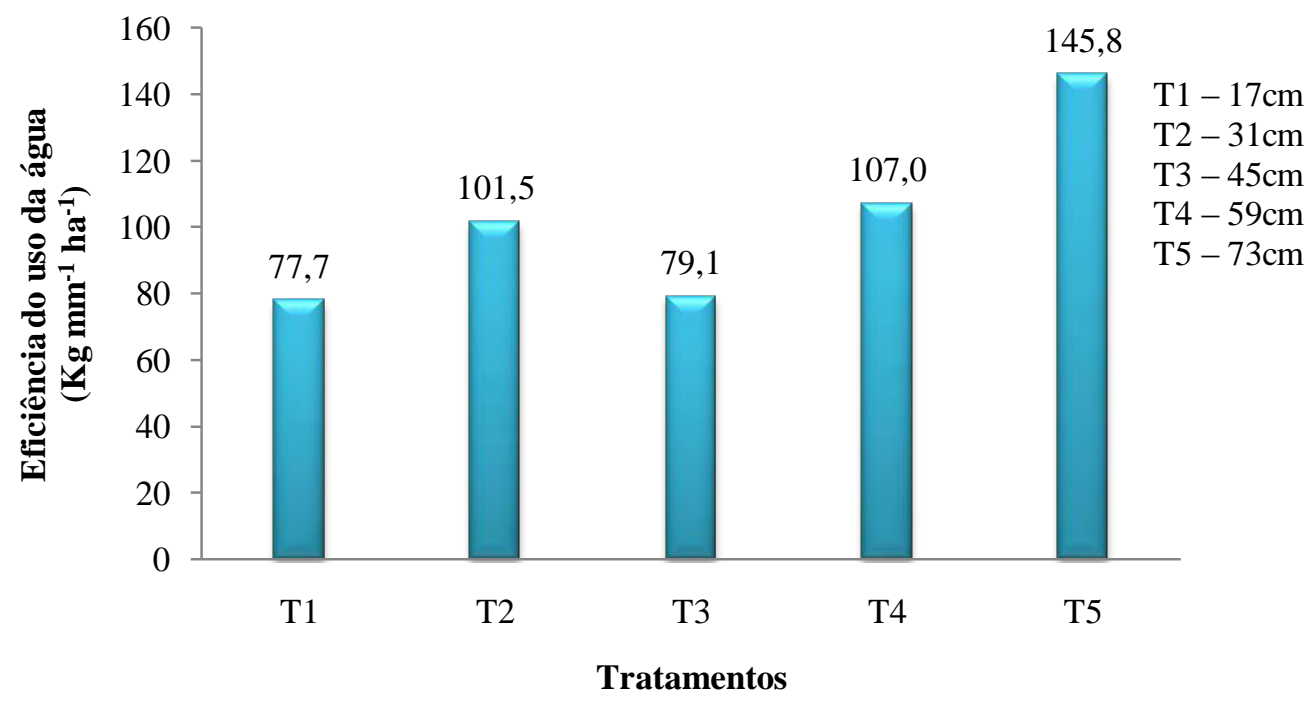

Figura 16. Eficiência do uso da água pelas plantas de sorgo (Sorghum bicolor L. Moench) submetidas a diferentes níveis de lençol freático. 


\section{CONCLUSÕES}

Os resultados nas condições deste experimento permitiram as seguintes conclusões:

1. foram observadas diferenças no desenvolvimento das plantas submetidas a diferentes níveis de lençol freático;

2. as profundidades de níveis de lençol freático abaixo de $73 \mathrm{~cm}$, não seriam recomendadas, pois não se observou emergência de plantas;

3. os tratamentos com nível de lençol freático à profundidade de 45 e $59 \mathrm{~cm}$ foram os mais precoces quanto ao florescimento;

4. profundidades de níveis freáticos menores que $17 \mathrm{~cm}$ não seriam recomendadas, pois se verificou o menor desenvolvimento do sistema radicular, prejudicando o desenvolvimento das plantas;

5. as profundidades com lençol freático entre 45 e $59 \mathrm{~cm}$ foram os melhores, apresentando os maiores valores para ambas as massas, fresca e seca das plantas;

6. para as panículas, os maiores valores para as massas de matéria fresca e seca, bem como o comprimento apresentaram tendência aos maiores valores para os níveis de lençol de 59 e $73 \mathrm{~cm}$;

7. com relação ao diâmetro do colmo, não houve significância estatística entre os tratamentos 45, 59 e $73 \mathrm{~cm}$, porém estes foram significativamente diferentes das cultivadas em níveis freáticos mais próximos da superfície, observando-se assim que os níveis de lençol freático mais profundos induziram as plantas a produzirem colmos mais grossos; 
8. a evapotranspiração da cultura apresentou valores entre 115 a 184,58 $\mathrm{mm}$ e, os valores de Kc (ETc/Eto) tiveram médias 0,47 no estádio inicial (da germinação à emissão da panícula) e 1,46 no estádio seguinte (início do florescimento ao final deste). 


\section{REFERÊNCIAS BIBLIOGRÁFICAS}

ABOUKHALED, A.; ALFARO, J. F.; SMITH, M. Los lisimetros. (Estudio FAO Riego y Drenaje, 39). Roma: FAO, 1986. 60p.

ALLEN, R. G.; PEREIRA L. S.; RAES, D.; SMITH, M. Crop evapotranspiration Guidelines for computing crop water requerimentes. Rome FAO, 1998. 301 p. (FAO Irrigation and Drainage, 56).

ALLEN, R.G.; SMITH, M.; PERRIER, A.; PEREIRA, L.S. An update for the definition of reference evapotranspiration. International Commission on Irrigation and Drainage, New Delhi, v.43, n.2, 93p, 1994.

ALVES, D. N. B.; ÁVILA, L.; KLAR, A. E. Simulação da ascensão capilar em colunas de solo. In:VII Congresso de Pós Graduação da ESAL, 1994, Lavras. Anais... Lavras: Escola Superior de Agricultura de Lavras, 1994. p. 3 - 4.

ABMS. ASSOCIAÇÃO BRASILEIRA DE MILHO E SORGO. Sorgo granífero, cultivo e utilização. Pelotas: Grupo Pró-Sorgo - Sul, 1989. 41p.

AVELAR, B. C.; MORAIS, A. R. Influência das épocas de plantio na cultura do sorgo granífero em solo de cerrado. Pesquisa Agropecuária Brasileira, Brasília, v.21, n.10, p.1055-1065, out.1986. 
BARRETO, A. G. T.; COSTA, R. C. L.; CRUZ, F. J. R.; CAMARGO, P. M. P.; LUZ, L. M. Respostas bioquímicas e fisiológicas das plantas de sorgo (Sorghum bicolor L. Moench) submetidas ao alagamento. In: VI Seminário de iniciação cientifica da UFRA e XII Seminário de iniciação científica da EMBRAPA, 2008, Belém. Anais... Belém: Universidade Federal Rural da Amazônia, 2008.

BLUM, A. Crop responses to drought and the interpretation of adaptation. In: BELHASSEN, E. Drought tolerance in higher plants. Genetical, physiological and molecular biological analysis. Dordrecht: Kluwer Academic. p.57-70, 1997.

BOIN,C. Utilização de volumoso para gado de corte. In: SIMPÓSIO DE GADO DE CORTE, 1., 1985, São Paulo, Anais... São Paulo: v.1., p. 38-61, 1985.

BURMAN, R.; POCHOP, L. O. Evaporation, evapotranspiration and climatic data. (Developments in atmospheric science, 22). Amsterdam: Elsevier, 1994. 58p.

CATI. Coordenadoria de Assistência Técnica Integral. Disponível em: http://www.cati.sp.gov.br/Cati/_produtos/SementesMudas/cultivares/SORGOFORRAGEIRO-CATISSORGO.pdf. Acesso em: 20 de março de 2009.

CEPAGRI. Centro de Pesquisas Meteorológicas e Climáticas Aplicadas à Agricultura. Disponível em: http://www.cpa.unicamp.br/outras-informacoes/clima_muni_086.html. Acesso em: 12 de dezembro de 2009.

COELHO, E.F.; OLIVEIRA, F C.; ARAÚJO, E.C.E.; VASCONCELOS, L.F.L.; LIMA, D. M. Distribuição do sistema radicular da mangueira sob irrigação localizada em solo arenoso de tabuleiros costeiros. Revista Brasileira de Fruticultura, Jaboticabal, v. 23, n. 2, p. 250-256, 2001.

CONAB. Companhia Nacional de Abastecimento. Série histórica da cultura. Disponível em: http://www.conab.gov.br/conabweb/index.php?PAG=131. Acesso em: 12 de dezembro de 2009.

CUMMINS, D.G. Yield and quality change with maturity of silage-type sorghum fodder. Agronomy Journal, v.73, p.988-990, 1981. 
DAKER, A. A água na agricultura. Irrigação e Drenagem. 6. ed. Rio de Janeiro: Freitas Bastos, 1984, 543p.

DEMARCHI, J.J.A.A.; BOIN, C.; BRAUN, G. A cultura do sorgo (Sorghum bicolor L. Moench) para produção de silagens de alta qualidade. Zootecnia, Nova Odessa, v.33, n.3, p.111-136, jul/set., 1995.

DENMEAD, O.T.; SHAW, R.H. Availability of soil water to plants as affected by soil moisture content and meteorological conditions. Agronomy Journal, Madison, v.43, p.385$390,1962$.

DINAR, A. Economic factors and opportunities as determinants of water use efficiency in agriculture. Irrigation Science, New York, v. 14, p. 47-52, 1993.

DOORENBOS, J.; PRUITT, W. O. Necessidades hídricas das culturas. Campina Grande, Universidade Federal da Paraíba (Estudos FAO Irrigação e Drenagem, 24), 1997. 204p.

DOORENBOS, J.; KASSAM, A. H.. Efeito da água no rendimento das culturas. Campina Grande, Universidade Federal da Paraíba (Estudos FAO Irrigação e Drenagem, 33), 1994. 306p.

DOORENBOS, J. Yield response to water. Roma: FAO, 1979. 180p.

DOORENBOS, J.; PRUITT, W.O. Guidelines for predicting crop water requirements. Rome: FAO, 1977. 194p.

FOLEGATTI, M. V. Avaliação do desempenho de um "Scheduler" na detecção do estresse hídrico em cultura de feijoeiro (Phaseolus vulgaris L.) irrigado com diferentes lâminas. 1988. 188f. Tese (Doutorado em Agronomia/Irrigação e Drenagem) - Escola Superior de Agricultura “Luiz de Queiroz”, Universidade de São Paulo, Piracicaba, 1988.

FRANCIS, C.A.; RUTGER, J.N. PALMER, A.F.E. A rapid method for plant leaf area estimation in maize (Zea mays L.). Crop Science, v. 9, p.537-539, 1969. 
FREIRE, J. C. Retenção de umidade em perfil Oxissol do município de Lavras, Minas Gerais. 1975, 76f. Dissertação (Mestrado em Agronomia) - Escola Superior de Agricultura "Luiz de Queiroz”, Universidade de São Paulo, Piracicaba, 1975.

FRONZA, D. Consumo de água da cultura da estévia (Stevia rebaudiana (Bert.) Bertoni) estimado por microlisímetro automático. 2002. 105f. Tese (Doutorado em Agronomia/Irrigação e Drenagem) - Escola Superior de Agricultura "Luiz de Queiroz", Universidade de São Paulo, Piracicaba, 2002.

GARRITY, D. P.; WATTS, D. G.; SULLIVAN, C. Y. Moisture deficits and grain sorghum performance: Evapotranspiration yield relationships. Agronomy Journal. Madison, v. 74, p. 815-820, 1982.

JENSEN, M.E. Water consuption by agricultural plants.In: KOSLOWSKI, T.T. (Ed.). Water deficits and plant growth. 2a edição. New York: Academic Press, 1969. v.2, p.1- 22.

KERBAUY, G. Fisiologia Vegetal. Guanabara Koogan, RJ, 2004, 452p.

KLAR, A. E. A água no sistema solo-planta-atmosfera. São Paulo: Nobel, 1984. p.408.

LUNARDI, D. M. C. Efeito da condição de umidade da superfície do solo na evapotranspiração de referência medida e estimada. 2000. 103 f. Tese (Livre Docência) Faculdade de Ciências Agronômicas, Universidade Estadual Paulista, Botucatu, 2000.

LUSK, J.W; KARAU, P.K.; BALOGO, D.O. et al. Brown midrib sorghum or corn silage for milk production. Journal of Dairy Science, v.67, p.1739-1744, 1984.

MACHADO, E.C.; PEREIRA, A.R.; FAHL, J.I.; ARRUDA, H.V.; SILVA, W.J. \& TEIXEIRA, J.P.F. Análise quantitativa do crescimento de quatro variedades de milho em três densidades de plantio, através de funções matemáticas ajustadas. Pesquisa Agropecuária Brasileira, Brasília, v. 17, p. 825-833,1982.

MACHADO, J. R.; NAKAGAWA, J.; ROSOLEM, C. A.; BRINHOLI, O. Épocas de semeadura de sorgo sacarino em São Manuel e Botucatu, Estado de São Paulo. Pesquisa Agropecuária Brasileira, Brasília, v.22, n.9/10, p.951-958, set./out.1987. 
MAGALHÃES, P. C.; DURÃES, F. O. M. Ecofisilogia da produção de sorgo: Sete Lagoas: EMBRAPA, 2003. 4p. (Comunicado Técnico, 87)

MAGALHÃES, P. C.; DURÃES, F. O. M.; RODRIGUES, J. A. S. Fisiologia da planta de sorgo: Sete Lagoas: EMBRAPA, 2003. 4p. (Comunicado Técnico, 86)

MAGALHÃES, P. C.; DURÃES, F. O. M.; PAIVA, E. Recuperação da cultura do sorgo após um período de déficit hídrico. In: CONGRESSO NACIONAL DE MILHO E SORGO, 20, 1994, Goiânia. Anais... Goiânia: ABMS. 1994. p. 186.

MAGALHÃES, A.C.N. Análise quantitativa do crescimento. In: FERRI, M.G. Fisiologia Vegetal. EPU/EDUSP, São Paulo. 1979. v. 1, p. 331-350.

MAPA. MINISTÉRIO DA AGRICULTURA, PECUÁRIA E ABASTECIMENTO.

Disponível em :

http://www.agricultura.gov.br/pls/portal/docs/PAGE/MAPA/ESTATISTICAS/CULTURAS/2.

2.A.XLS. Acesso em: 26 jan. 2009.

MEDEIROS, G.A.; ARRUDA, F.B.; SAKAI, E.; FUJIWARA, M. The influence of crop canopy on evapotranspiration and crop coefficient of beans (Phaseolus vulgaris L.). Agric. Water Manage. V.49, p.211-224, 2001.

MOHAN, S.; ARUMUGAM, N. Crop coefficients of major crops in south India. Agricultural Water Management, v. 26, p. 67-80, 1994.

MONTGOMERY, E.G. Correlation studies of com. Annual report. Nebraska Agricultural Experiment Station, v. 1, n. 24, p. 108-159, 1911.

MOURA, M. V. T.; BOTREL, T. A. ; FRIZZONE, J. A. Determinação do consumo de água na cultura da cenoura (Daucus carota L.). Engenharia rural, Piracicaba, v. 4, p. 89-101, 1993.

MUÇOUÇAH, M. F. S. Crescimento de bulbos de calla cultivados em substrato em função do nível freático. 2005. 92F. Tese (Doutorado em Agronomia/Irrigação e Drenagem) - Faculdade de Ciências Agronômicas, Universidade Estadual Paulista, Botucatu, 2005. 
PAULETTO, E. A.; LIBARDI, P. L.; MANFRON, P. A.; MORAES, S. O. Determinação da condutividade hidráulica de solos a partir da curva de retenção de água. Revista Brasileira de Ciência do Solo, n. 12, p. 189-195, 1988.

OLIVEIRA, L. A. Condições de aplicação de água em cinco cultivares de trigo em ambiente protegido. 2009. 68f. Tese (Doutorado em Agronomia/Irrigação e Drenagem) Faculdade de Ciências Agronômicas, Universidade Estadual Paulista, Botucatu, 2009.

PAVANI, L. C. Evapotranspiração e produtividade em feijoeiro comum (Phaselus vulgaris, cv Goiano Precoce) sob três níveis de potencial de água no solo. 1985, 171 p. (Mestrado em Irrigação e Drenagem), Escola Superior de Agricultura Luiz de Queiróz, Universidade de São Paulo, Piracicaba, 1985.

PEARCE, R.B.; MOCK, J J . \& BAILEY, T.B. Rapid method for estimating leaf area per plant in maize. Crop Science, 15:691-694,1975.

PEREIRA, A. R.; VILLA NOVA, N. A.; SEDIYAMA, G. C. Evapo(transpi)ração. Piracicaba: FEALQ, 1997. 183p.

PERES, J. C. Avaliação do modelo de Penmam-Monteith, padrão FAO, para estimar a evapotranspiração de referência nas condições climáticas do Estado de São Paulo. 1994. 115f. Tese (Doutorado em Irrigação e Drenagem) - Escola Superior de Agricultura "Luiz de Queiroz", Universidade de São Paulo, Piracicaba, 1994.

PETERS, J.A.; MADRUGA, L.A.M.; MORAES, D.M.; PAULETTO, E.A. Efeito da profundidade de semeadura, temperatura e umidade do solo sobre a emergência do sorgo sacarino. In: REUNIÃO TECNICA ANUAL DO SORGO, 11, Pelotas, 1982. Anais... Pelotas: EMBRAPA-UEPAE, 1982. p.122-6.

PRADOS, N. C. Contribuicion al estudio de los cultivos enarenados em Almeria: necessidades hídricas y extración del nutrientes del cultivo de tomate de crescimento indeterminado en abrigo de polietileno. Almeria, 1986. 195p. Tesis (Doctoral)

RAIJ, B. van; CANTARELLA, H.; QUAGGIO, J.A. FURLANI, A.M.C. (Ed). Recomendações de adubação e calagem para o Estado de São Paulo. 2. ed. Campinas: Instituto Agronômico, 1997. 285 p. (IAC. Boletim Técnico, 100). 
RAMALHO, M. A. P.; SANTOS, J. B.; ZIMMERMANN, M. J. O.de. Interação dos genótipos x ambientes. In: RAMALHO, M. A. P.; SANTOS, J. B.; ZIMMERMANN, M. J. O. Genética quantitativa em plantas autógamas: aplicações ao melhoramento do feijoeiro. Goiânia: UFG, 1993. p.131-169.

REICHARDT, K. Dinâmica da matéria e da energia em ecossistemas. 2. ed. Piracicaba: ESALQ, Depto. De Física e Meteorología, 1996.

REICHARDT, K. A água em sistemas agrícolas. São Paulo: Editora Manoele, 1990. 188p. REIS, O.V. Seleção de linhagens de sorgo forrageiro (Sorghum bicolor (L.) Moench) tolerantes ao estresse hídrico em fase de plântula. 1992. 150p. (Mestrado em Botanica) Universidade Federal Rural de Pernambuco, Recife, 1992.

RIBAS, P.M. Sorgo: introdução e importância econômica. Sete Lagoas: Embrapa Milho e Sorgo, 2003. 16p. (Embrapa Milho e Sorgo. Documentos, 26).

RODRIGUEZ, L. C. Evapotranspiracion. Madrid: Departamento de Publicaciones, Escuela Tecnica Superior de Ingenieros Agronomos, 1968. 89p.

ROSENTHAL, W. D.; ARKIN, G. F.; SHOUSE, P. J. Water deficit effects on transpiration and leaf growth. Agronomy Journal, Madison, v. 79, p. 1019-1026, 1987.

SAWAZAKI, E. Sorgo forrageiro ou misto, sorgo granífero, sorgo vassoura - Sorghum bicolor Moench. In: FAHL, J.I., et al. Instruções agrícolas para as principais culturas econômicas. (IAC. Boletim, 200), 6. ed. rev. atual. Campinas: IAC, 1998. p.44-49.

SCAPIM, C.A.; RODRIGUES, J.A.S.; CRUZ, C.D.; CECON, P.R.; RIBEIRO JUNIOR, J.I.; BRACCINI, A.L. Efeitos gênicos, Heterose e depressão endogâmica em caracteres de sorgo forrageiro. Bragantia, Campinas, v. 57, n.1, p. 81-94, 1998.

SCHEUERMANN, N.G. Utilização do sorgo em rações para frangos de corte, Concordia: EMBRAPA-CNPSA (EMBRAPACNPSA COMUNICADO TÉCNICO), 1998. 3p.

SEDIYAMA, G. C. Necessidade de água para os cultivos. In: ASSOCIAÇÃO BRASILEIRA DE ENSINO AGRÍCOLA SUPERIOR. Curso de engenharia de irrigação. Brasília, 1987. 143p. 
SILVA, A. G.; ROCHA, V. S.; CRUZ, C. D.; SEDIYAMA, T. PINTO, G. H. F. Adaptabilidade e estabilidade de cultivares de sorgo forrageiro semeados em diferentes épocas do ano. Revista Brasileira de Milho e Sorgo, v.4, n.1, p.112-125, 2005

SILVEIRA, M. H. D.; KLAR, A. E. Produção de matéria seca e evapotranspiração real da aveia preta (Avena strigosa S.) em seis níveis freáticos. Revista Irriga, v. 01, 2006.

SMITH, M. et al. Reporto $n$ the expert consultation on procedures for revision of FAO guidelines for prediction of crop water requirements. Roma: FAO, 1991. 45p.

STANHILL, G. Water use efficiency. Adv. Agron., v.39, p. 53-85, 1986.

STICKLER, F. C.; WEARDEN, S.; PAULI, A. W. Leaf area determination in grain sorghum. Agronomy journal, Madison, v. 53, p. 187-188. 1961.

SOUZA, V. F.; COELHO, E. F.; ANDRADE JUNIOR, A. S.; FOLEGATTI, M. V.; FRIZZONE, J. A. Eficiência do uso da água pelo meloeiro sob diferentes frequiências de irrigação. Revista Brasileira de Engenharia Agrícola e Ambiental., v. 4, n. 2, p. 183-8, 2000 .

TANNER, C. B.; SINCLAIR, T. R. Efficient water use in crop production. Research or research?. In: TAYLOR, H. M. et al. Limitations to efficient water use in crop production. Madison: ASA, 1983. p. 1-27.

VALADÃO, L. T. Evapotranspiração e coeficientes da cultura do feijoeiro (Phaseolus vulgaris L.) em dois níveis de lençol freático. 1995. 112f. Dissertação (Mestrado em Agronomia/Irrigação e Drenagem) - Faculdade de Ciências Agronômicas, Universidade Estadual Paulista, Botucatu, 1995.

VALENTE, J.O. Introdução. In: MANEJO CULTURAL DO SORGO PARA FORRAGEM. Circular técnica, Embrapa- CNPMS, Sete Lagoas, MG, n.17, p.5-7. 1992.

VIEIRA, S.R.; REYNOLDS, W.D. \& TOPP, G.C. Spatial variability of hydraulic properties in a highly structuredclay soil. Department of Agronomy and Horticulture, New Mexico State University, p.471-483, 1988. 
WINTER, S.R., OHLROGGE, A.J. Leaf angle, leaf area, and corn (Zea mays L.) yield. Agronomy Journal, v.65, n.3, p.395-97, 1973.

WRIGHT, L. New evapotranspiration crop coefficients. Journal of the Irrigation and Drainage, New York, v.108, p.57-75, 1982. 